\title{
Molecular Biomarkers for Gestational Diabetes Mellitus
}

\author{
Stephanie Dias ${ }^{1,2}$, Carmen Pheiffer ${ }^{1,3}{ }^{(1)}$, Yoonus Abrahams ${ }^{1,3}$, Paul Rheeder ${ }^{4}$ and \\ Sumaiya Adam $2, *$ (D) \\ 1 Biomedical Research and Innovation Platform, South African Medical Research Council, P.O. Box 19070, \\ Tygerberg, Cape Town 7505, South Africa; Stephanie.Dias@mrc.ac.za (S.D.); \\ carmen.pheiffer@mrc.ac.za (C.P.); Yoonus.Abrahams@mrc.ac.za (Y.A.) \\ 2 Department of Obstetrics and Gynecology, University of Pretoria, Private Bag X169, Pretoria 0001, \\ South Africa \\ 3 Division of Medical Physiology, Faculty of Health Sciences, Stellenbosch University, P.O. Box 19063, \\ Tygerberg, Cape Town 7505, South Africa \\ 4 Department of Internal Medicine, Faculty of Health Sciences, University of Pretoria, Private Bag X169, \\ Pretoria 0001, South Africa; paul.rheeder@up.ac.za \\ * Correspondence: Sumaiya.adam@up.ac.za; Tel: +27-84-951-1773
}

Received: 31 August 2018; Accepted: 22 September 2018; Published: 26 September 2018

\begin{abstract}
Gestational diabetes mellitus (GDM) is a growing public health problem worldwide. The condition is associated with perinatal complications and an increased risk for future metabolic disease in both mothers and their offspring. In recent years, molecular biomarkers received considerable interest as screening tools for GDM. The purpose of this review is to provide an overview of the current status of single-nucleotide polymorphisms (SNPs), DNA methylation, and microRNAs as biomarkers for GDM. PubMed, Scopus, and Web of Science were searched for articles published between January 1990 and August 2018. The search terms included "gestational diabetes mellitus", "blood", "single-nucleotide polymorphism (SNP)", "DNA methylation", and "microRNAs", including corresponding synonyms and associated terms for each word. This review updates current knowledge of the candidacy of these molecular biomarkers for GDM with recommendations for future research avenues.
\end{abstract}

Keywords: molecular biomarkers; gestational diabetes mellitus; DNA methylation; microRNAs; single-nucleotide polymorphism; genetic and epigenetic markers

\section{Introduction}

Gestational diabetes mellitus (GDM) is defined as glucose intolerance with onset or first recognition during pregnancy [1]. The prevalence of GDM is increasing worldwide, with approximately $14 \%$ of pregnancies affected by GDM [2]. The condition is associated with perinatal complications and an increased risk for future metabolic disease in both mothers and their offspring. The oral glucose tolerance test (OGTT) is considered the gold standard for the diagnosis of GDM [3]. However, the test is cumbersome to conduct, requires fasting and multiple blood draws, and its association with nausea and vomiting leads to decreased patient compliance. Furthermore, the OGTT is conducted between 24-28 weeks of gestation [3], presenting a small window of opportunity to implement interventions to improve pregnancy outcomes. Earlier detection of GDM may lead to improved management, possibly preventing pregnancy complications. Thus, the identification of sensitive and specific biomarkers, which may offer potential for risk prediction and intervention strategies, became a major focus in GDM research. Several studies provided evidence for a genetic predisposition to GDM [4], while gene-environment interactions could explain the population-specific variation in GDM 
prevalence [5]. Consequently, single-nucleotide polymorphisms (SNPs) and epigenetic mechanisms are widely explored as molecular biomarkers for GDM.

The purpose of this review is to provide an overview of the current status of SNPs and the two most commonly investigated epigenetic mechanisms, DNA methylation and microRNAs (miRNAs), as molecular biomarkers for GDM. Three major databases, PubMed, Scopus, and Web of Science, were searched for studies published between January 1990 and August 2018 that investigated SNPs, DNA methylation, and miRNAs in the blood of women with GDM. Blood was selected as it is easily accessible as part of routine antenatal care. The search terms included "gestational diabetes mellitus", "blood", "single-nucleotide polymorphism (SNP)", "DNA methylation", and "microRNAs", including corresponding synonyms and associated terms for each word (Appendix A, Table A1). Articles were selected if they reported case-control studies that investigated GDM in association with SNPs, DNA methylation, or miRNAs in maternal blood, plasma, or serum, and were conducted in humans. This review begins with an overview of GDM, followed by a brief description of the characteristics of ideal biomarkers. Thereafter, studies profiling SNPs and DNA methylation in whole blood, and miRNAs in whole blood, plasma, or serum of women with GDM are summarized, and the limitations of these molecular biomarkers are discussed. Finally, the current status of GDM biomarkers is discussed, along with recommendations for future research.

\section{Overview of Gestational Diabetes Mellitus}

The exact mechanism underlying the development of GDM is not completely understood; however, it is speculated that women who develop GDM are unable to meet the increasing demand for insulin production during pregnancy [6]. GDM is associated with an increased risk of shortand long-term pregnancy complications. Women with GDM have a higher risk of pre-eclampsia, Caesarean section, and birth injury, while postpartum complications to offspring include macrosomia, shoulder dystocia, hyperinsulinemia, hypoglycemia, and hyperbilirubinemia [7-9]. In the long term, both mothers and their offspring are predisposed to metabolic conditions such as obesity, type 2 diabetes (T2D), and cardiovascular disease [10]. Estimates are that approximately $30 \%$ of offspring [11] and more than $70 \%$ of women with previous cases of GDM [12] are predisposed to develop type T2D later in life, thus posing significant health and economic burdens to health systems.

Recently, several studies provided evidence that early detection and treatment of GDM improve health outcomes [13]. Consequently, universal screening for GDM is advocated by most international organizations [14]. However, only women who have traditional risk factors for GDM (obesity, ethnicity, advanced maternal age, glycosuria, and previous adverse pregnancy outcomes) $[15,16]$ are recommended for the OGTT in resource-limited settings. Unfortunately, these risk factors have poor predictive value, resulting in many women with GDM not receiving appropriate treatment [17]. Thus, there is significant impetus to identify biomarkers of GDM. Serum proteins such as adiponectin, insulin, sex hormone globulin, C-reactive protein, and glycosylated fibronectin are widely studied $[15,18-20]$, while the diagnostic utility of glycated hemoglobin $(\mathrm{HbA1c})$ was also explored [21]. However, these potential biomarkers are yet to achieve clinical applicability. Evidence for genetic susceptibility [22] and dysregulated epigenetic regulation, in particular DNA methylation [23] and miRNAs [24], is increasingly being reported during GDM, sparking interest in their use as molecular biomarkers.

\section{Characteristics of Ideal Biomarkers}

Biomarkers are indicators of normal biological processes that can be used to detect disease or other biological states of organisms. They are considered clinically useful because they can potentially predict or diagnose disease, give insight into the pathophysiology of disease, and can be used to monitor pharmacological responses to therapeutic intervention or to predict clinical outcome [25]. Recent advancements in molecular biology led to the development of molecular biomarkers that are easily measured in biological fluids such as whole blood, plasma, and serum. The ideal biomarker 
should be cost effective and reproducible, easily accessible through non-invasive methods, stably expressed in biological fluids, sensitive to relevant changes in disease state, provide early detection of disease before clinical symptoms arise, and have the ability to differentiate between disease pathologies [26,27]. Commercial kits for SNPs [28], DNA methylation [29], and miRNAs [30] are already clinically available for a number of other disorders.

\section{Single-Nucleotide Polymorphisms}

Single-nucleotide polymorphisms (SNPs) refer to alterations in the DNA sequence at individual nucleotide bases. They are the most common genetic variation, with over 10 million SNPs present in the human genome [31]. In most cases SNPs are silent, not altering the function or expression of genes [32], while others are biologically functional, and can lead to altered protein function and disease. The search for SNPs that influence disease susceptibility and outcome is a field of active research. Several studies provided evidence that SNPs are associated with metabolic conditions including obesity, T2D, and cardiovascular disease [33]. Variants in more than 50 and 80 loci were found to be associated with obesity [34] and T2D [35], respectively, and occur in genes that regulate glucose homeostasis and insulin signaling.

\subsection{Single-Nucleotide Polymorphisms and Gestational Diabetes Mellitus}

Genetic variants are increasingly being implicated in the pathogenesis of GDM [4]. Evidence suggests that genetic alterations in genes responsible for metabolic changes during pregnancy predispose one to GDM. In this review, a total of 76 studies were identified that investigated SNPs during GDM, using the search terms previously stated. However, to increase the likelihood of reporting a true association, only SNPs investigated in two or more populations were reported. Thirty-four SNPs investigated in 49 studies met the inclusion criteria and are summarized in Table 1.

Genetic studies of the transcription factor 7 like 2 (TCF7L2) gene, which is arguably one of the most important T2D susceptibility genes [36], produced varying results in GDM [37-46]. TCF7L2 encodes a transcription factor, which is involved in Wnt signaling, an important pathway that regulates glucose homeostasis. Twenty studies conducted in diverse populations screened four SNPs (rs7903146, rs4506565, rs7901695, and rs12255372) in the TCF7L2 gene. Four of the eight studies that investigated rs7903146 showed an association between the T allele and GDM [37,38,43,44]. The other studies failed to observe an association between rs7903146 and GDM, possibly due to small sample size and a lack of statistical power. [40-42]. Both studies investigating rs4506565 reported an association between the $\mathrm{T}$ allele and GDM [37,41]. One of the five studies investigating rs7901695 found an association between GDM and the T allele in American Caucasians [46], while one study found that the $C$ allele, rather than the $\mathrm{T}$ allele, was associated with GDM in a large Swedish population [43]. The three studies that did not show an association had relatively small sample sizes [40,41,45]. Of the five studies investigating rs12255372, two showed an association between the T allele and GDM, one was conducted in a large Swedish population and the other in a small Mexican population [42,43]. However, these results were not replicated in studies conducted in Russian, Spanish, or Brazilian populations [39,41,47] of moderate size, suggesting that ethnic or other confounding factors underlie these differences. The T allele is associated with decreased insulin production and altered hepatic gluconeogenesis [48], and therefore, is a good candidate for further research in larger cohorts, despite these conflicting results obtained in these studies.

Adiponectin $(A D I P O Q)$ is an adipokine that regulates glucose and lipid metabolism $[49,50]$, which was associated with GDM in many studies. Three SNPs within the ADIPOQ gene, rs1501299, rs266729, and rs2241766, were investigated in eight studies. Markedly, all six studies that investigated rs266729 [51,52] and rs2241766 [52-55] found that the G allele was associated with GDM in various populations. Both studies investigating rs1501299 showed no association between this SNP and GDM [51,52]. 
The melanotonin receptor $1 \mathrm{~B}$ gene (MTNR1B) encodes one of the receptors for melatonin, a hormone that is involved in regulating circadian rhythms, insulin signaling, and glucose metabolism, amongst others [56]. Two SNPs, rs10830963 and rs1387153, within the MTNR1B gene were investigated. Eight of the nine studies that screened rs10830963 showed that the G allele was associated with an increased risk for GDM in several Caucasian populations [37,39,44,46,57,58], as well as in Chinese and South Korean populations $[59,60]$. However, Wang et al. found that this SNP was not associated with GDM in a different Chinese population [61]. The three studies that investigated rs1387153 reported an association between the T allele and GDM $[37,39,60]$. Variants in MTNR1B, particularly the G allele of rs10830963, were previously shown to be associated with increased fasting glucose concentrations and reduced beta-cell function in Caucasians [62].

Glucokinase (GCK) and the glucokinase regulator (GCKR) play critical roles in glucose processing in the liver [63]. Two variants, rs1799884 and rs4607517, within the GCK gene were studied for GDM. For rs1799884, the minor allele, reported as either T [39] or A [64], was associated with an increased risk of GDM. Tarnowski et al. also showed a trend toward a significant association between the $\mathrm{T}$ allele and risk of GDM in a Polish population [65]. However, a large study in a Finnish population showed no association between rs1799884 and GDM [44]. No association between rs4607517 and GDM was observed [44,61]. Within the GCKR gene, the C allele of rs780094 was associated with an increased risk of GDM in Malaysian, American Caucasian, and Brazilian populations [46,66,67], but not in studies conducted in Polish or Finnish populations [44,65]. The $C$ allele was increased in women with GDM from the Polish population, but this did not reach significance due to a lack of statistical power.

The association between genetic variants within the fat mass and obesity-associated (FTO) gene and metabolic syndrome is widely reported [68]. FTO encodes an alpha-ketoglutarate-dependent dioxygenase, which plays a role in adipocyte development and function [69]. Three SNPs within the FTO gene were studied for GDM. Of the six studies investigating rs9939609, one study in a Finnish population found an association between the A allele and an increased risk for GDM [44], another study in a small Spanish population found an association between the T allele and GDM [41], while four studies reported no association $[38,39,47,70]$. Discrepancies between the studies are possibly due to ethnic and genotyping method differences. None of the studies investigating rs8050136 and rs1421085 found an association between these SNPs and GDM $[45,47,70]$.

Insulin receptor substrate 1 (IRS1) is a protein that plays a key role in transmitting signals from the insulin and insulin-like growth factor-1 receptors to intracellular pathways that are associated with insulin response and risk of T2D [71]. Two genetic variants, rs1801278 and rs7578326, within IRS1 were investigated during GDM. For rs1801278, the T allele was associated with an increased risk of GDM [72] in a Saudi Arabian population, but not in a Russian population [39], while, for rs7578326, the $\mathrm{G}$ allele was associated with a decreased risk of GDM in an Austro-Hungarian population [58], but not in a Finnish population [44]. As previously stated, these conflicting results may be due to population and genotyping method differences.

Potassium voltage-gated channel subfamily Q member 1 (KCNQ1) plays a role in insulin secretion, and variants of KCNQ1 are associated with decreased insulin secretion and increased susceptibility to T2D [73]. Two variants, rs2237895 and rs2237892, were investigated in different populations in four studies. In both variants, the $C$ allele was associated with an increased risk of GDM [74-76]. The solute carrier family 30 member 8 (SLC30A8) gene encodes a zinc transporter protein that plays a role in insulin secretion, and variants of the gene are associated with T2D risk [77]. Rs13266634 was investigated in three studies with varying results. One study showed that the $\mathrm{T}$ allele was associated with a decreased risk of GDM in an Austro-Hungarian population, while the $\mathrm{C}$ allele was found to be associated with an increased risk of GDM in a large Swedish population [58,78]. A large Finnish population showed no association between rs13266634 and GDM [44].

As illustrated in Table 1, SNPs in 13 other genes were investigated in two studies; however, these showed either a positive association in one study only, or no association with GDM. Of these, SNPs within nine genes, cyclin-dependent kinase 5 (CDK5) regulatory-subunit-associated protein 1 like 
(CDKAL1), calpain 10 (CAPN10), potassium voltage-gated channel subfamily J member 11 (KCNJ11), retinol-binding protein 4 (RBP4), group-specific component (GC), serine/threonine kinase 11 (STK11), macrophage migration inhibitory factor $(M I F), C D K$ inhibitor 2A/2B $(C D K N 2 A / 2 B)$, and insulin-like growth factor 2 messenger RNA (mRNA)-binding protein 2 (IGF2BP2), were associated with GDM in one population only, while SNPs within four genes, cluster of differentiation 36 (CD36) molecule , peroxisome proliferator-activated receptor gamma 2 (PPARG2), vitamin D receptor (VDR), cell division cycle 123 homolog/calmodulin-dependent protein kinase ID (CDC123/CAMK1D), were not associated with GDM in any of the populations investigated.

\subsection{Limitations of Single-Nucleotide Polymorphisms}

There are inherent limitations in genetic association studies, particularly in studies of polygenic and multifactorial diseases such as GDM. As stated above, these limitations include inadequate sample size to detect statistically significant associations, and differences in allele frequencies and disease etiology between ethnicities, which may explain why many genetic associations are not reproducible across populations. Furthermore, GDM diagnosis is not standardized internationally; thus, different diagnostic criteria could have contributed to the discordant results observed between studies. Importantly, genetic variants do not solely contribute to the development of complex diseases, and it is widely believed that disease arise due to the interaction of genetic predisposition and environmental factors [79]. Thus, to accurately assess risk of GDM, biological and environmental factors, such as maternal age and diet [39], should be considered together with genetic variants.

Despite the variable results obtained across studies, many of the variants found to be associated with GDM, are also associated with T2D, supporting their biological plausibility. Therefore, while the etiology of GDM may differ from T2D, the genetic pathways through which the symptoms manifest are likely to overlap. In this review, only studies that profiled SNPs in DNA extracted from whole blood were reported on. However, the use of less invasive sources of genetic material, such as buccal swabs, is acknowledged [80]. Furthermore, this review only included SNPs reported in two or more studies, and may have overlooked other important SNPs possibly associated with GDM. 
Table 1. Studies reporting on single-nucleotide polymorphisms (SNPs) profiled in two or more populations with gestational diabetes mellitus (GDM).

\begin{tabular}{|c|c|c|c|c|c|c|c|}
\hline Author & Gene & $\begin{array}{c}\text { SNP } \\
\text { Identification }\end{array}$ & Country & $\begin{array}{l}\text { Detection } \\
\text { Method }\end{array}$ & Case/Control & $\begin{array}{c}\text { Associated Allele or } \\
\text { Genotype }\end{array}$ & Risk for GDM \\
\hline Ding et al., 2018 [37] & TCF7L2 & rs7903146 & Denmark and USA & qRT-PCR & $2636 / 6086$ & T allele & Increased \\
\hline $\begin{array}{l}\text { Franzago et al., } \\
2018[38]\end{array}$ & & & Italy & HRM & $104 / 124$ & T allele & Increased \\
\hline $\begin{array}{l}\text { Popova et al., } \\
2017 \text { [39] }\end{array}$ & & & Russia & qRT-PCR & $278 / 179$ & No association & - \\
\hline $\begin{array}{l}\text { Michalak-Wojnowska } \\
\text { et al., 2016 [40] }\end{array}$ & & & Poland & qRT-PCR & $50 / 26$ & No association & - \\
\hline $\begin{array}{l}\text { Pagán et al., } \\
2014[41]\end{array}$ & & & Spain & Sequencing & $45 / 25$ & No association & - \\
\hline $\begin{array}{l}\text { Reyes-López et al., } \\
2014 \text { [42] }\end{array}$ & & & Mexico & RFLP & $90 / 108$ & No association & - \\
\hline $\begin{array}{l}\text { Papadopoulou et al., } \\
2011 \text { [43] }\end{array}$ & & & Sweden & qRT-PCR & $826 / 1185$ & T allele & Increased \\
\hline $\begin{array}{l}\text { Huopio et al., } \\
2013 \text { [44] }\end{array}$ & & & Finland & MassARRAY & $533 / 407$ & $\mathrm{~T}$ allele & Increased \\
\hline Ding et al., 2018 [37] & & rs4506565 & Denmark and USA & qRT-PCR & $2636 / 6086$ & T allele & Increased \\
\hline $\begin{array}{l}\text { Pagán et al., } \\
2014 \text { [41] }\end{array}$ & & & Spain & Sequencing & $45 / 25$ & T allele & Increased \\
\hline $\begin{array}{l}\text { Anghebem-Oliveira, } \\
\text { et al., } 2017 \text { [45] }\end{array}$ & & rs7901695 & Brazil & qRT-PCR & $127 / 125$ & No association & - \\
\hline $\begin{array}{l}\text { Michalak-Wojnowska } \\
\text { et al., 2016 [40] }\end{array}$ & & & Poland & qRT-PCR & $50 / 26$ & No association & - \\
\hline $\begin{array}{l}\text { Pagán et al., } \\
2014 \text { [41] }\end{array}$ & & & Spain & Sequencing & $45 / 25$ & No association & - \\
\hline $\begin{array}{l}\text { Stuebe et al., } \\
2014 \text { [46] }\end{array}$ & & & USA African American (AA) and Caucasian (C) & MassARRAY & 26/362 (AA) and 56/843 (C) & $\begin{array}{c}\text { No association (AA) } \\
\text { T allele (C) }\end{array}$ & $\begin{array}{c}- \\
\text { Increased }\end{array}$ \\
\hline $\begin{array}{c}\text { Papadopoulou et al., } \\
2011 \text { [43] }\end{array}$ & & & Sweden & qRT-PCR & $805 / 1116$ & C allele & Increased \\
\hline $\begin{array}{l}\text { Popova et al., } \\
2017 \text { [39] }\end{array}$ & & rs12255372 & Russia & qRT-PCR & $278 / 179$ & No association & - \\
\hline $\begin{array}{l}\text { de Melo et al., } \\
2015 \text { [47] }\end{array}$ & & & Brazil & qRT-PCR & $200 / 200$ & No association & - \\
\hline $\begin{array}{l}\text { Pagán et al., } \\
2014 \text { [41] }\end{array}$ & & & Spain & Sequencing & $45 / 25$ & No association & - \\
\hline $\begin{array}{c}\text { Reyes-López et al., } \\
2014 \text { [42] }\end{array}$ & & & Mexico & RFLP & $90 / 108$ & T allele & Increased \\
\hline
\end{tabular}


Table 1. Cont.

\begin{tabular}{|c|c|c|c|c|c|c|c|}
\hline Author & Gene & $\begin{array}{c}\text { SNP } \\
\text { Identification }\end{array}$ & Country & $\begin{array}{l}\text { Detection } \\
\text { Method }\end{array}$ & Case/Control & $\begin{array}{c}\text { Associated Allele or } \\
\text { Genotype }\end{array}$ & Risk for GDM \\
\hline $\begin{array}{c}\text { Papadopoulou et al., } \\
2011 \text { [43] }\end{array}$ & & & Sweden & qRT-PCR & $826 / 1185$ & T allele & Increased \\
\hline $\begin{array}{l}\text { Pawlik et al., } \\
2017 \text { [51] }\end{array}$ & $A D I P O Q$ & rs1501299 & Poland & qRT-PCR & $204 / 207$ & No association & - \\
\hline $\begin{array}{l}\text { Beltcheva et al., } \\
2014 \text { [52] }\end{array}$ & & & Bulgaria & qRT-PCR & $130 / 130$ & No association & - \\
\hline $\begin{array}{l}\text { Pawlik et al., } \\
2017 \text { [51] }\end{array}$ & & rs266729 & Poland & qRT-PCR & $204 / 207$ & G allele & Increased \\
\hline $\begin{array}{l}\text { Beltcheva et al., } \\
2014 \text { [52] }\end{array}$ & & & Bulgaria & qRT-PCR & $130 / 130$ & G allele & Increased \\
\hline $\begin{array}{l}\text { Takshid et al., } \\
2015 \text { [53] }\end{array}$ & & rs2241766 & Iran & RFLP & $65 / 70$ & G allele & Increased \\
\hline Han et al., 2014 [55] & & & China & RFLP & $128 / 140$ & G allele & Increased \\
\hline $\begin{array}{l}\text { Beltcheva et al., } \\
2014 \text { [52] }\end{array}$ & & & Bulgaria & qRT-PCR & $130 / 130$ & G allele & Increased \\
\hline Low et al., 2011 [54] & & & Malaysia & RFLP & $26 / 53$ & G allele & Increased \\
\hline Ding et al., 2018 [37] & MTNR1B & rs10830963 & Denmark and USA & qRT-PCR & $2636 / 6086$ & G allele & Increased \\
\hline Li et al., 2018 [59] & & & China & Sequencing & $215 / 243$ & G allele & Increased \\
\hline $\begin{array}{l}\text { Tarnowski et al., } \\
2017 \text { [57] }\end{array}$ & & & Poland & qRT-PCR & $204 / 207$ & G allele & Increased \\
\hline Rosta et al., 2017 [58] & & & Hungary and Austria & KASP & $287 / 533$ & G allele & Increased \\
\hline $\begin{array}{l}\text { Popova et al., } \\
2017 \text { [39] }\end{array}$ & & & Russia & qRT-PCR & $278 / 179$ & G allele & Increased \\
\hline $\begin{array}{l}\text { Stuebe et al., } \\
2014[46]\end{array}$ & & & USA African American (AA) and Caucasian (C) & MassARRAY & $\begin{array}{c}\text { 26/362 (AA) and } \\
56 / 843(\mathrm{C})\end{array}$ & $\begin{array}{c}\text { No association (AA) } \\
G \text { allele (C) }\end{array}$ & $\begin{array}{c}- \\
\text { Increased }\end{array}$ \\
\hline $\begin{array}{l}\text { Wang et al., } \\
2011[61]\end{array}$ & & & China & qRT-PCR & $725 / 1039$ & No association & - \\
\hline Kim et al., 2011 [60] & & & South Korea & qRT-PCR & $928 / 990$ & G allele & Increased \\
\hline $\begin{array}{l}\text { Huopio et al., } \\
2013 \text { [44] }\end{array}$ & & & Finland & MassARRAY & $533 / 407$ & G allele & Increased \\
\hline Ding et al., 2018 [37] & & rs1387153 & Denmark and USA & qRT-PCR & $2636 / 6086$ & T allele & Increased \\
\hline $\begin{array}{l}\text { Popova et al., } \\
2017 \text { [39] }\end{array}$ & & & Russia & qRT-PCR & $278 / 179$ & T allele & Increased \\
\hline Kim et al., 2011 [60] & & & South Korea & qRT-PCR & $928 / 990$ & T allele & Increased \\
\hline $\begin{array}{l}\text { Tarnowski et al., } \\
2017 \text { [65] }\end{array}$ & GCK & rs1799884 & Poland & qRT-PCR & $204 / 207$ & No association & - \\
\hline
\end{tabular}


Table 1. Cont

\begin{tabular}{|c|c|c|c|c|c|c|c|}
\hline Author & Gene & $\begin{array}{c}\text { SNP } \\
\text { Identification }\end{array}$ & Country & $\begin{array}{l}\text { Detection } \\
\text { Method }\end{array}$ & Case/Control & $\begin{array}{c}\text { Associated Allele or } \\
\text { Genotype }\end{array}$ & Risk for GDM \\
\hline $\begin{array}{l}\text { Popova et al., } \\
2017 \text { [39] }\end{array}$ & & & Russia & qRT-PCR & $278 / 179$ & $\mathrm{~T}$ allele & Increased \\
\hline Han et al., 2015 [64] & & & China & $\begin{array}{l}\text { PCR Invader } \\
\text { assay }\end{array}$ & $948 / 975$ & $\mathrm{~A} *$ allele & Increased \\
\hline $\begin{array}{l}\text { Huopio et al., } \\
2013 \text { [44] }\end{array}$ & & & Finland & MassARRAY & $533 / 407$ & No association & - \\
\hline $\begin{array}{l}\text { Wang et al., } \\
2011 \text { [61] }\end{array}$ & & rs4607517 & China & qRT-PCR & $725 / 1039$ & No association & - \\
\hline $\begin{array}{l}\text { Huopio et al., } \\
2013 \text { [44] }\end{array}$ & & & Finland & MassARRAY & $533 / 407$ & No association & - \\
\hline $\begin{array}{c}\text { Jamalpour et al., } \\
2018 \text { [66] }\end{array}$ & GCKR & rs780094 & Malaysia & MassARRAY & $267 / 855$ & C allele & Increased \\
\hline $\begin{array}{c}\text { Tarnowski et al., } \\
2017 \text { [65] }\end{array}$ & & & Poland & qRT-PCR & $204 / 207$ & No association & - \\
\hline $\begin{array}{l}\text { Anghebem-Oliveira et al., } \\
2017 \text { [67] }\end{array}$ & & & Brazil & qRT-PCR & $127 / 125$ & C allele & Increased \\
\hline $\begin{array}{l}\text { Stuebe et al., } \\
2014 \text { [46] }\end{array}$ & & & USA African American (AA) and Caucasian (C) & MassARRAY & $\begin{array}{c}26 / 362(\mathrm{AA}) \text { and } \\
56 / 843(\mathrm{C})\end{array}$ & $\begin{array}{c}\text { No association } \\
\text { C allele }\end{array}$ & $\begin{array}{c}- \\
\text { Increased }\end{array}$ \\
\hline $\begin{array}{l}\text { Huopio et al., } \\
2013 \text { [44] }\end{array}$ & & & Finland & MassARRAY & $533 / 407$ & No association & - \\
\hline $\begin{array}{c}\text { Franzago et al., } \\
\quad 2018[38]\end{array}$ & FTO & rs9939609 & Italy & HRM & $104 / 124$ & No association & - \\
\hline $\begin{array}{l}\text { Saucedo et al., } \\
2017 \text { [70] }\end{array}$ & & & Mexico & qRT-PCR & $80 / 80$ & No association & - \\
\hline $\begin{array}{l}\text { Popova et al., } \\
2017 \text { [39] }\end{array}$ & & & Russia & qRT-PCR & $278 / 179$ & No association & - \\
\hline $\begin{array}{l}\text { de Melo et al., } \\
2015 \text { [47] }\end{array}$ & & & Brazil & qRT-PCR & $200 / 200$ & No association & - \\
\hline $\begin{array}{l}\text { Pagán et al., } \\
2015 \text { [41] }\end{array}$ & & & Spain & Sequencing & $45 / 25$ & $\mathrm{~T}$ allele & Increased \\
\hline $\begin{array}{l}\text { Huopio et al., } \\
2013[44]\end{array}$ & & & Finland & MassARRAY & $533 / 407$ & A allele & Increased \\
\hline $\begin{array}{l}\text { Saucedo et al., } \\
2017 \text { [70] }\end{array}$ & & rs8050136 & Mexico & qRT-PCR & $80 / 80$ & No association & - \\
\hline $\begin{array}{l}\text { de Melo et al., } \\
2015 \text { [47] }\end{array}$ & & & Brazil & qRT-PCR & $200 / 200$ & No association & - \\
\hline
\end{tabular}


Table 1. Cont.

\begin{tabular}{|c|c|c|c|c|c|c|c|}
\hline Author & Gene & $\begin{array}{c}\text { SNP } \\
\text { Identification }\end{array}$ & Country & $\begin{array}{l}\text { Detection } \\
\text { Method }\end{array}$ & Case/Control & $\begin{array}{c}\text { Associated Allele or } \\
\text { Genotype }\end{array}$ & Risk for GDM \\
\hline $\begin{array}{l}\text { Saucedo et al., } \\
2017 \text { [70] }\end{array}$ & & rs1421085 & Mexico & qRT-PCR & $80 / 80$ & No association & - \\
\hline $\begin{array}{l}\text { Anghebem-Oliveira et al., } \\
2017 \text { [45] }\end{array}$ & & & Brazil & qRT-PCR & $127 / 125$ & No association & - \\
\hline $\begin{array}{l}\text { Popova et al., } \\
2017[39]\end{array}$ & IRS1 & rs1801278 & Russia & qRT-PCR & $278 / 179$ & No association & - \\
\hline $\begin{array}{l}\text { Alharbi et al., } \\
2014 \text { [72] }\end{array}$ & & & Saudi Arabia & RFLP & $200 / 300$ & $\mathrm{~T}$ allele & Increased \\
\hline $\begin{array}{l}\text { Huopio et al., } \\
2013 \text { [44] }\end{array}$ & & rs7578326 & Finland & MassARRAY & $533 / 407$ & No association & - \\
\hline Rosta et al., 2017 [58] & & & Hungary and Austria & KASP & $287 / 533$ & G allele & Decreased \\
\hline $\begin{array}{l}\text { Fatima et al., } \\
2016 \text { [74] }\end{array}$ & KCNQ1 & rs2237895 & Pakistan & RFLP/sequencing & $208 / 429$ & $\mathrm{C}$ allele & Increased \\
\hline $\begin{array}{l}\text { Kwak et al., } \\
2010 \text { [75] }\end{array}$ & & & South Korea & qRT-PCR & $869 / 632$ & No association & - \\
\hline Ao et al., 2015 [76] & & rs2237892 & China & MassARRAY & $562 / 453$ & $\mathrm{C}$ allele & Increased \\
\hline $\begin{array}{l}\text { Kwak et al., } \\
2010 \text { [75] }\end{array}$ & & & South Korea & qRT-PCR & $869 / 632$ & $\mathrm{C}$ allele & Increased \\
\hline Rosta et al., 2017 [58] & SLC30A8 & rs13266634 & Hungary and Austria & KASP & $287 / 533$ & $\mathrm{~T}$ allele & Decreased \\
\hline $\begin{array}{l}\text { Dereke et al., } \\
2016 \text { [78] }\end{array}$ & & & Sweden & RFLP & $776 / 511$ & C allele & Increased \\
\hline $\begin{array}{l}\text { Huopio et al., } \\
2013 \text { [44] }\end{array}$ & & & Finland & MassARRAY & $533 / 407$ & No association & - \\
\hline $\begin{array}{l}\text { Noury et al., } \\
2018 \text { [81] }\end{array}$ & $C D K A L 1$ & rs7754840 & Egypt & qRT-PCR & $47 / 51$ & No association & - \\
\hline Rosta et al., 2017 [58] & & & Hungary and Austria & KASP & $287 / 533$ & $\mathrm{C}$ allele & Increased \\
\hline $\begin{array}{l}\text { Popova et al., } \\
2017 \text { [39] }\end{array}$ & & & Russia & qRT-PCR & $278 / 179$ & No association & - \\
\hline $\begin{array}{l}\text { Wang et al., } \\
2011 \text { [61] }\end{array}$ & & & China & qRT-PCR & $725 / 1039$ & No association & - \\
\hline $\begin{array}{l}\text { Huopio et al., } \\
2013 \text { [44] }\end{array}$ & & & Finland & MassARRAY & $533 / 407$ & No association & - \\
\hline $\begin{array}{l}\text { Castro-Martinez et al., } \\
\text { 2018 [82] }\end{array}$ & CAPN10 & SNP43 & Mexico & $\begin{array}{l}\text { qRT-PCR \& } \\
\text { RFLP }\end{array}$ & $116 / 83$ & No association & - \\
\hline $\begin{array}{l}\text { Leipold et al., } \\
2004 \text { [83] }\end{array}$ & & & Austria & RFLP & $100 / 100$ & No association & - \\
\hline
\end{tabular}


Table 1. Cont.

\begin{tabular}{|c|c|c|c|c|c|c|c|}
\hline Author & Gene & $\begin{array}{c}\text { SNP } \\
\text { Identification }\end{array}$ & Country & $\begin{array}{l}\text { Detection } \\
\text { Method }\end{array}$ & Case/Control & $\begin{array}{l}\text { Associated Allele or } \\
\text { Genotype }\end{array}$ & Risk for GDM \\
\hline $\begin{array}{l}\text { Castro-Martinez et al., } \\
2018 \text { [82] }\end{array}$ & & SNP63 & Mexico & $\begin{array}{l}\text { qRT-PCR \& } \\
\text { RFLP }\end{array}$ & $116 / 83$ & No association & - \\
\hline $\begin{array}{l}\text { Leipold et al., } \\
2004 \text { [83] }\end{array}$ & & & Austria & RFLP & $40 / 40$ & C allele & Increased \\
\hline $\begin{array}{l}\text { Huopio et al., } \\
2013[44]\end{array}$ & & & Finland & MassARRAY & $533 / 407$ & No Association & - \\
\hline $\begin{array}{l}\text { Lenin et al., } \\
2018 \text { [84] }\end{array}$ & KCNJ11 & rs5219 & India & RFLP & $230 / 240$ & $\mathrm{~T}$ allele & Increased \\
\hline $\begin{array}{l}\text { Popova et al., } \\
2017[39]\end{array}$ & & & Russia & qRT-PCR & 278/179 & No association & - \\
\hline $\begin{array}{l}\text { Huopio et al., } \\
2013[44]\end{array}$ & & & Finland & MassARRAY & $533 / 407$ & No association & - \\
\hline $\begin{array}{l}\text { Saucedo et al., } \\
2014[85]\end{array}$ & RBP4 & rs3758539 & Mexico & qRT-PCR & $100 / 100$ & No association & - \\
\hline Ping et al., 2012 [86] & & & China & LDR & $505 / 687$ & G allele & Increased \\
\hline $\begin{array}{l}\text { Hiraoka et al., } \\
2011[87]\end{array}$ & & & $\begin{array}{c}\text { USA Caucasian (C), Filipino (F), and Pacific } \\
\text { Islander (PI) }\end{array}$ & qRT-PCR & $\begin{array}{l}88 / 315(\mathrm{C}), 82 / 286(\mathrm{~F}) \\
\text { and } 19 / 32(\mathrm{PI})\end{array}$ & No association & - \\
\hline Shi et al., 2016 [88] & GC & rs16847024 & China & MassARRAY & $964 / 1021$ & $\mathrm{~T}$ allele & Increased \\
\hline $\begin{array}{l}\text { Wang et al., } \\
2015 \text { [89] }\end{array}$ & & & China & qRT-PCR & $692 / 802$ & No association & - \\
\hline $\begin{array}{l}\text { Alharbi et al., } \\
2015[90]\end{array}$ & STK11 & rs8111699 & Saudi Arabia & RFLP & $200 / 300$ & No association & - \\
\hline $\begin{array}{l}\text { Bassols et al., } \\
2013[91]\end{array}$ & & & Spain & qRT-PCR & $243 / 318$ & G allele & Decreased \\
\hline $\begin{array}{l}\text { Aslani et al., } \\
2011[92]\end{array}$ & MIF & rs1007888 & Iran & PCR-SSP & $147 / 169$ & G allele & Increased \\
\hline $\begin{array}{l}\text { Huopio et al., } \\
2013[44]\end{array}$ & & & Finland & MassARRAY & $533 / 407$ & No association & - \\
\hline $\begin{array}{l}\text { Noury et al., } \\
2018 \text { [81] }\end{array}$ & $C D K N 2 A / 2 B$ & rs10811661 & Egypt & qRT-PCR & $47 / 51$ & No association & - \\
\hline Ye et al., 2016 [93] & & & Poland & qRT-PCR & $204 / 207$ & $C$ allele & Decreased \\
\hline $\begin{array}{l}\text { Huopio et al., } \\
2013[44]\end{array}$ & & & Finland & MassARRAY & $533 / 407$ & No association & - \\
\hline $\begin{array}{l}\text { Popova et al., } \\
2017[39]\end{array}$ & IGF2BP2 & rs4402960 & Russia & qRT-PCR & $278 / 179$ & No association & - \\
\hline $\begin{array}{l}\text { Wang et al., } \\
2015 \text { [89] }\end{array}$ & & & China & qRT-PCR & $725 / 1039$ & T allele & Increased \\
\hline
\end{tabular}


Table 1. Cont.

\begin{tabular}{|c|c|c|c|c|c|c|c|}
\hline Author & Gene & $\begin{array}{c}\text { SNP } \\
\text { Identification }\end{array}$ & Country & $\begin{array}{l}\text { Detection } \\
\text { Method }\end{array}$ & Case/Control & $\begin{array}{c}\text { Associated Allele or } \\
\text { Genotype }\end{array}$ & Risk for GDM \\
\hline $\begin{array}{l}\text { Huopio et al., } \\
2013 \text { [44] }\end{array}$ & & & Finland & MassARRAY & $533 / 407$ & No association & - \\
\hline $\begin{array}{c}\text { Bartákova et al., } \\
2018 \text { [94] }\end{array}$ & $C D 36$ & rs1527479 & Czech Republic & qRT-PCR & $293 / 70$ & No association & - \\
\hline Yang et al., 2018 [95] & & & China & qRT-PCR & $209 / 215$ & No association & - \\
\hline $\begin{array}{l}\text { Franzago et al., } \\
\quad 2018 \text { [38] }\end{array}$ & PPARG2 & rs1801282 & Italy & HRM & $104 / 124$ & No association & - \\
\hline $\begin{array}{l}\text { Anghebem-Oliveira et al., } \\
2017 \text { [45] }\end{array}$ & & & Brazil & qRT-PCR & $127 / 125$ & No association & - \\
\hline Shi et al., 2016 [88] & $V D R$ & rs739837 & China & MassARRAY & $964 / 1021$ & No association & - \\
\hline $\begin{array}{l}\text { Wang et al., } \\
2015 \text { [89] }\end{array}$ & & & China & qRT-PCR & $692 / 802$ & No association & - \\
\hline $\begin{array}{c}\text { Tarnowski et al., } \\
2017 \text { [96] }\end{array}$ & CDC123/CAMK1D & rs1277970 & Poland & qRT-PCR & $204 / 207$ & No association & - \\
\hline $\begin{array}{c}\text { Huopio et al., } \\
2013 \text { [44] }\end{array}$ & & & Finland & MassARRAY & $533 / 407$ & No association & - \\
\hline
\end{tabular}

RFLP—restriction fragment length polymorphism of PCR-amplified fragments; KASP-kompetitive allele specific PCR; qRT-PCR-quantitative real-time PCR (TaqMan allelic discrimination assay); LDR-ligase detection reaction; HRM—high-resolution melt-curve analysis; MassARRAY—Sequenom MassARRAY iPLEX platform; USA-United States of America; PCR invader assay - invasive cleavage reaction which uses a structure-specific flap endonuclease. * A is the minor allele also reported as T. TCF7L2-transcription factor 7 like 2; $A D I P O Q$-adiponectin; MTNR1B—melatonin receptor 1B; CAPN10—calpain 10; CDKAL1—cyclin-dependent kinase 5 (CDK5) regulatory-subunit-associated protein 1 like; $C D K N 2 A / 2 B$ - CDK inhibitor 2A/2B; FTO—fat mass And obesity-associated; GC-group-specific component (vitamin-D-binding protein); GCK-glucokinase; GCKR - glucokinase Regulator; IGF2BP2-insulin-like growth factor 2 messenger RNA (mRNA)-binding protein 2; IRS1-insulin receptor substrate 1; KCNJ11-potassium voltage-gated channel subfamily J member 11: KCNO1_potassium voltage-gated channel subfamily Q member 1; RBP4-retinol-binding protein 4; SLC30A8-solute carrier family 30 member 8; STK11—-serine/threonine kinase 11; MIF-macrophage migration inhibitory factor; CD36-cluster of differentiation 36 molecule; PPARG2-peroxisome proliferator-activated receptor gamma 2; VDR-vitamin D receptor; $C D C 123 / C A M K 1 D$ — cell division cycle 123 homolog/calmodulin-dependent protein kinase ID. 


\section{DNA Methylation}

DNA methylation, the most widely studied and best characterized epigenetic mechanism, occurs via the addition of a methyl group to the fifth carbon position of a cytosine residue within cytosine-phosphate-guanine ( $\mathrm{CpG}$ ) dinucleotides [97]. The process is catalyzed by the enzyme DNA methyltransferase (DNMT), with S-adenosyl-methionine serving as the methyl donor. Methylation of CpG islands, which are regions with high levels of $\mathrm{CpG}$ dinucleotides primarily in the promoter regions of genes, is generally associated with transcriptional repression due to altered protein binding to target sites on DNA $[98,99]$. DNA methylation is a reversible process [100]. Ten-eleven translocation (TET) methylcytosine dioxygenases are able to cause the oxidation and demethylation of methylated cytosine to 5-hydroxymethylcytosine [100], which is associated with gene activation. Recently, DNA methylation of CpG-poor islands was identified downstream of active promoters, either within (intragenic) or between (intergenic) genes, although the role of methylation in these regions are not fully elucidated [101]. Approximately 55-90\% of all CpG dinucleotides within CpG islands are methylated, constituting about $3 \%$ of the genome. Global DNA hypomethylation is associated with genomic and chromosomal instability, while DNA methylation within the promoters of genes is generally associated with gene silencing. Both aberrant global and gene-specific DNA methylation was shown to be associated with metabolic conditions such as obesity [102], T2D [103], and cardiovascular disease [104]. Thus, characterization of altered DNA methylation during disease processes could give insight into the pathophysiology of disease, and reveal novel diagnostic, prognostic, and therapeutic targets.

\subsection{DNA Methylation and Gestational Diabetes Mellitus}

DNA methylation during pregnancy plays a key role in modulating the transcriptional potential of the genome, and is known to affect gene expression pathways associated with a range of pathophysiological processes such as GDM $[49,105]$. Several studies demonstrated that DNA methylation is altered in the placenta and cord blood of women with GDM compared to women with normoglycemic pregnancies [23,106-109]. Intrauterine exposure to GDM leads to long-lasting effects in the offspring and increases risk of disease in later life, possibly mediated by DNA methylation [110,111]. Importantly, it was demonstrated that physiological and DNA methylation changes that occur during pregnancy are reflected in whole blood [112], thus increasing interest in screening maternal blood for biomarkers of GDM. DNA methylation profiling in pregnancies complicated by GDM is a relatively new research field, with limited studies conducted in maternal whole blood. Studies that investigated DNA methylation in whole blood of women with GDM are summarized in Table 2.

Global DNA methylation provides an estimate of overall genomic methylation and is relatively easy and cost-effective to measure [113]. Currently, the only study that investigated global DNA methylation during GDM was conducted in our laboratory [114]. The study showed that global DNA methylation was not associated with GDM in a South African population, suggesting that the method may be too crude to detect subtle glucose intolerance, and that gene-specific methylation is warranted in this population. Genome-wide DNA methylation profiling in maternal blood during GDM was conducted using methylation bead chip arrays [115-117]. Methylation bead chip arrays can interrogate between 27,000 and 850,000 CpG sites across the genome at a single-nucleotide resolution. In one of the earliest studies using bead chip arrays, Enquobahrie et al. reported that DNA methylation changes occurred early during pregnancy in six women with repeat pregnancies, one of which was complicated by GDM [116]. They reported that $17 \mathrm{CpG}$ sites were hypomethylated and $10 \mathrm{CpG}$ sites were hypermethylated between GDM and normal pregnancies within the same women. Novel genes related to these CpG sites were found to be associated with cell cycle, cell morphology, cell assembly, cell organization, and cell compromise. Subsequently, using a newer bead chip array containing more CpG sites, Kang et al. showed that 200 CpGs corresponding to 151 genes were differentially methylated in women with GDM $(n=8)$ compared to controls $(n=8)$. Amongst the differentially methylated genes were interleukin-6 (IL-6) and interleukin-10 (IL-10), which are key pro-inflammatory and anti-inflammatory cytokines, respectively [115]. These cytokines function in a wide variety 
of inflammatory-associated diseases, including obesity and T2D. Moreover, a different study by Kang et al. showed that decreased methylation of IL-10 during GDM was associated with increased serum IL-10 concentrations at the end of pregnancy [118]. IL-10 serum concentrations were shown to vary during pregnancy, suggesting that this cytokine plays an important role in the development of GDM. In another study using bead chip arrays, 100 differentially methylated CpG sites corresponding to 66 genes were identified in women with GDM $(n=11)$ compared to controls $(n=11)$ [117]. Using more stringent statistical criteria to prioritize methylation sites, a total of five $\mathrm{CpG}$ sites within the constitutive photomorphogenic homolog subunit 8 (COPS8), phosphoinositide 3-kinase regulatory subunit 5 (PIK3R5), 3-hydroxyanthranilate 3,4-dioxygenase (HAAO), coiled-coil domain containing 124 (CCDC124), and chromosome 5 open reading frame 34 (C5orf34) genes were identified and validated using pyrosequencing. Since blood for DNA methylation profiling was collected prior to GDM diagnosis, these $\mathrm{CpG}$ sites may prove useful as predictive biomarkers for GDM. However, their candidacy as biomarkers requires validation in larger studies.

\subsection{Limitations of DNA Methylation}

Although studies show that DNA methylation has potential as a diagnostic and prognostic biomarker, they are not without limitations [119]. Several factors, including small sample size, lack of validation, differences in ethnicity, method of quantification, and timing of methylation analysis during pregnancy, hinder reproducibility of findings across studies. Another limitation of the studies included in this review is the use of whole blood, which consists of a mixture of cell types such as lymphocytes, erythrocytes, and platelets, and may confound methylation analysis [120]. Thus, future studies should consider purification of blood-cell populations to separate specific cell types. Currently, there is no consensus on the best method to use for DNA methylation analysis. While global DNA methylation can easily be measured using crude DNA preparations, it is a measure of overall genomic methylation and does not offer the resolution required to detect subtle DNA methylation differences within genes [121]. In contrast, locus-specific DNA methylation methods such as bead chip arrays and pyrosequencing are expensive, requiring sophisticated equipment and bioinformatics expertise. 
Table 2. Studies investigating DNA methylation in whole blood during gestational diabetes mellitus.

\begin{tabular}{|c|c|c|c|c|}
\hline Author & Study Design & Country & Detection Method & Main Finding \\
\hline Dias et al., 2018 [114] & $\begin{array}{l}63 \mathrm{GDM} \text { and } 138 \text { controls } \\
\text { ( 26 weeks gestation) }\end{array}$ & South Africa & $\begin{array}{l}\text { Global DNA methylation using MDQ1 } \\
\text { Imprint DNA Quantification Kit* }\end{array}$ & $\begin{array}{l}\text { No difference in global DNA methylation between } \\
\text { women with or without GDM. Global DNA } \\
\text { methylation was associated with obesity and } \\
\text { serum adiponectin concentrations. }\end{array}$ \\
\hline $\begin{array}{l}\text { Enquobahrie et al., } \\
2015 \text { [116] }\end{array}$ & $\begin{array}{l}6 \text { women with } 2 \text { consecutive } \\
\text { pregnancies with and without } \\
\text { GDM }(<20 \text { weeks gestation })\end{array}$ & United States & $\begin{array}{l}\text { Illumina HumanMethylation27 } \\
\text { BeadChip }\end{array}$ & $\begin{array}{c}17 \text { CpG sites were hypomethylated and } 10 \mathrm{CpG} \\
\text { sites were hypermethylated in relation to } \\
\text { GDM status }\end{array}$ \\
\hline Kang et al., 2017 [115] & $\begin{array}{l}8 \text { GDM and } 8 \text { controls } \\
\text { (end of pregnancy) }\end{array}$ & Taiwan & $\begin{array}{l}\text { Illumina Infinium } \\
\text { HumanMethylationEPIC BeadChip }\end{array}$ & $\begin{array}{l}200 \text { differentially methylated CpGs corresponding } \\
\text { to } 151 \text { genes identified in women with GDM } \\
\text { compared to controls }\end{array}$ \\
\hline Kang et al., 2018 [118] & $\begin{array}{l}8 \mathrm{GDM} \text { and } 24 \text { controls } \\
\text { (end of pregnancy) }\end{array}$ & Taiwan & MethyLight qRT-PCR assay & $\begin{array}{c}\text { Decreased methylation of IL-10 during GDM, } \\
\text { which was associated with increased serum IL-10 } \\
\text { concentrations }\end{array}$ \\
\hline Wu et al., 2018 [117] & $\begin{array}{l}11 \text { GDM and } 11 \text { controls } \\
\text { (12-16 weeks gestation) }\end{array}$ & United Kingdom & $\begin{array}{l}\text { Illumina HumanMethylation } 450 \\
\text { BeadChip (450K) array and bisulfite } \\
\text { pyrosequencing }\end{array}$ & $\begin{array}{l}100 \text { differentially methylated CpGs corresponding } \\
\text { to } 66 \text { genes were identified. Differential DNA } \\
\text { methylation at } 5 \text { CpGs were validated in } 8 \text { of the } \\
11 \text { GDM women }\end{array}$ \\
\hline
\end{tabular}

qRT-PCR—quantitative real-time PCR; CpG—cytosine-phosphate-guanine; IL-10—interleukin-10; GDM—gestational diabetes mellitus. * Sigma-Aldrich. St. Louis, USA. 


\section{MicroRNAs}

MiRNAs are short, highly conserved non-coding RNA molecules, approximately 22 nucleotides in length, which are powerful mediators of biological function. They regulate gene expression through post-transcriptional mechanisms by binding to the $3^{\prime}$ untranslated region (UTR) of messenger RNA (mRNA), inducing gene silencing through translational repression or mRNA degradation [122]. This interaction is dependent on the complementarity of the miRNA to the "miRNA seed region", a region of seven or eight nucleotides contained within the $3^{\prime}$ UTR of mRNA. MiRNA binding requires a number of nucleotides to match the sequence flanking the seed region to direct the specificity of miRNA-mRNA interactions $[123,124]$. Since their initial discovery in Caenorhabditis elegans in 1993 [125], over 2000 miRNAs were identified in humans, and they are believed to regulate about one-third of the genome [126].

MiRNAs are master regulators that control many biological processes including cell proliferation, differentiation, apoptosis, and development [127]. Moreover, they regulate genes involved in metabolic processes such as glucose homeostasis, insulin signaling, pancreatic beta-cell function, lipid metabolism, and inflammation [128]. Their dysregulation was reported during many metabolic conditions, including obesity, T2D, and cardiovascular disease [129-131]. Although they exert their function intracellularly, several studies identified extracellular circulating miRNAs, which sparked interest in their use as biomarkers of disease [132]. Circulating miRNAs are associated with various complexes such as lipoproteins, exosomes, apoptotic bodies, microvesicles, and ribonucleoproteins such as Argonaute (Ago)1-4 or nucleophosphin 1 (NPM1), which serve to protect these miRNAs from nuclease degradation, and act as carriers to transport them to their target mRNAs. This suggests that miRNAs function in cell-to-cell communication, regulating gene expression in neighboring cells by either acting locally (paracrine or autocrine signaling) or at a distance (endocrine/exocrine) [132,133].

\subsection{MicroRNAs and Gestational Diabetes Mellitus}

MiRNAs are important metabolic and developmental regulators during pregnancy, and were shown to play a role in the development of GDM. In 2013, genome-wide analysis demonstrated that more than 600 miRNAs are expressed in the placenta [134]. Recently, Poirer et al. reviewed placental miRNAs that are dysregulated during pregnancy and GDM [135]. The placenta plays an important role in maternal metabolic adaptation to pregnancy, and differential expression of placental miRNAs are believed to partly underlie these physiological changes. Placental miRNAs are released into maternal circulation [112]; thus, these miRNAs hold potential as biomarkers of placental dysfunction and GDM. Studies reporting circulating miRNA expression during GDM are summarized in Table 3.

In 2011, Zhao et al. were the first to profile the expression of serum miRNAs during GDM [136]. Using Taqman low-density arrays, followed by confirmation with individual qRT-PCR, they identified three miRNAs, miR-132, miR-29a, and miR-222, that were significantly downregulated in Chinese women with GDM $(n=24)$ compared to controls $(n=24)$ [136]. The differential expressions of miR-29a and miR-222 were validated in an internal and two external validation cohorts. These miRNAs are thought to play a role in glucose homeostasis, insulin sensitivity, and beta-cell function [136]. A number of studies in other populations replicated these experiments with conflicting results. Recently, Pheiffer et al. reported decreased expression of miR-132, miR-29a, and miR-222 in the serum of South African women with GDM $(n=28)$ compared to controls $(n=53)$; however, only the latter was statistically significant [5]. These findings demonstrate that the expression of these serum miRNAs are shared across South African and Chinese populations. In contrast to Zhao et al., Tagnoma et al. showed that miR-222 expression was increased in plasma of women with GDM $(n=13)$ compared to controls $(n=9)$ [137]. Wander et al. observed no differences in the expression of miR-222 or miR-29a in the plasma of American Caucasian women with GDM $(n=36)$ compared to controls $(n=80)$ [138]. These discrepancies may be due to differences in biological samples used (serum or plasma), gestational age, or other unknown factors not accounted for. 
Table 3. Studies investigating circulating microRNAs (miRNAs) during gestational diabetes mellitus.

\begin{tabular}{|c|c|c|c|c|c|c|c|c|}
\hline Author & Study Design & Country & $\begin{array}{l}\text { Biological } \\
\text { Source }\end{array}$ & $\begin{array}{l}\text { Detection } \\
\text { Method }\end{array}$ & Upregulated & Downregulated & $\begin{array}{l}\text { No Significant } \\
\text { Change }\end{array}$ & $\begin{array}{l}\text { Normalization } \\
\text { Control }\end{array}$ \\
\hline $\begin{array}{l}\text { Zhao et al., } \\
2011 \text { [136] }\end{array}$ & $\begin{array}{c}24 \text { GDM and } 24 \text { controls } \\
\text { (16-19 weeks gestation); } \\
36 \text { GDM and } 36 \text { controls } \\
\text { (internal validation); } \\
16 \text { GDM and } 16 \text { controls } \\
\text { (external validation) }\end{array}$ & China & Serum & $\begin{array}{c}\text { Taqman } \\
\text { low-density } \\
\text { array, qRT-PCR }\end{array}$ & - & $\begin{array}{l}\text { miR-29a, } \\
\text { miR-132, } \\
\text { miR-222 }\end{array}$ & - & $\begin{array}{c}\text { Cel-miR-39 } \\
\text { (exogenous control) }\end{array}$ \\
\hline $\begin{array}{c}\text { Pheiffer et al., } \\
2018 \text { [5] }\end{array}$ & $\begin{array}{l}28 \text { GDM and } 53 \text { controls } \\
\text { (13-31 weeks gestation) }\end{array}$ & South Africa & Serum & qRT-PCR & - & $\begin{array}{l}\text { miR-20a, } \\
\text { miR-222 }\end{array}$ & $\begin{array}{l}\text { miR-16, miR-17, } \\
\text { miR-19a, miR-19b, } \\
\text { miR-29a, miR-132 }\end{array}$ & $\begin{array}{c}\text { Cel-miR-39 } \\
\text { (exogenous control) }\end{array}$ \\
\hline $\begin{array}{l}\text { Tagnoma et al., } \\
2018 \text { [137] }\end{array}$ & $\begin{array}{l}13 \text { GDM and } 9 \text { controls } \\
\text { (23-31 weeks gestation) }\end{array}$ & Estonia & Plasma & qRT-PCR & $\begin{array}{c}\text { let-7e, let-7g, miR-100, } \\
\text { miR-101, miR-146a, } \\
\text { miR-8a, miR-195, } \\
\text { miR-222, miR-23b, } \\
\text { miR-30b, miR-30c, } \\
\text { miR-30d, miR-342, } \\
\text { miR-423, miR-92a }\end{array}$ & - & - & $\begin{array}{c}\text { Cel-miR-39 } \\
\text { (exogenous control) }\end{array}$ \\
\hline $\begin{array}{l}\text { Wander et al., } \\
2017 \text { [138] }\end{array}$ & $\begin{array}{l}36 \text { GDM and } 80 \text { controls } \\
\text { (7-23 weeks gestation) }\end{array}$ & USA & Plasma & qRT-PCR & miR-155, miR-21 & & $\begin{array}{c}\text { miR-146b, miR-517, } \\
\text { miR-222, miR-210, } \\
\text { miR-518a, miR-29a, } \\
\text { miR-223, miR-126 }\end{array}$ & $\begin{array}{c}\text { Cel-miR-39 } \\
\text { (exogenous control) } \\
\text { and miR-423 } \\
\text { (endogenous control) }\end{array}$ \\
\hline $\begin{array}{l}\text { Zhu et al., } \\
2015 \text { [139] }\end{array}$ & $\begin{array}{l}10 \text { GDM and } 10 \text { controls } \\
\text { (16-19 weeks gestation) }\end{array}$ & China & Plasma & $\begin{array}{l}\text { Ion Torrent } \\
\text { sequencing, } \\
\text { qRT-PCR }\end{array}$ & $\begin{array}{l}\text { miR-16, miR-17, } \\
\text { miR-19a, miR-19b, } \\
\text { miR-20a }\end{array}$ & - & - & $\begin{array}{c}\text { miR-221 } \\
\text { (endogenous control) }\end{array}$ \\
\hline $\begin{array}{l}\text { Cao et al., } \\
2017 \text { [140] }\end{array}$ & $\begin{array}{l}85 \text { GDM and } 72 \text { controls } \\
\text { (16-20, 20-24, and } 24-28 \\
\text { weeks gestation) }\end{array}$ & China & Plasma & qRT-PCR & $\begin{array}{l}\text { miR-16, miR-17, } \\
\text { miR-20a }\end{array}$ & - & $\begin{array}{l}\text { miR-19a } \\
\text { miR-19b }\end{array}$ & $\begin{array}{c}\text { RNU6 } \\
\text { (endogenous control) }\end{array}$ \\
\hline $\begin{array}{l}\text { Sebastiani et al., } \\
2017 \text { [141] }\end{array}$ & $\begin{array}{l}21 \text { GDM and } 10 \text { controls } \\
\text { (24-33 weeks gestation) }\end{array}$ & Italy & Plasma & qRT-PCR & $\operatorname{miR}-330$ & - & $\operatorname{miR}-548 \mathrm{c}$ & $\begin{array}{l}\text { miR-374, miR-320 } \\
\text { (endogenous control) }\end{array}$ \\
\hline $\begin{array}{l}\text { Stirm et al., } \\
2018 \text { [142] }\end{array}$ & $\begin{array}{l}30 \text { GDM and } 30 \text { controls } \\
\text { (24-32 weeks gestation) }\end{array}$ & Germany & Whole blood & qRT-PCR & miR-340 & - & - & $\begin{array}{c}\text { RNU6B } \\
\text { (endogenous control) }\end{array}$ \\
\hline $\begin{array}{c}\text { He et al., } \\
2017 \text { [143] }\end{array}$ & $20 \mathrm{GDM}$ and 20 controls & China & Whole blood & qRT-PCR & - & miR-494 & - & $\begin{array}{c}\text { RNU6 } \\
\text { (endogenous control) }\end{array}$ \\
\hline $\begin{array}{l}\text { Lamadrid- } \\
\text { Romero et al., } \\
2018 \text { [144] }\end{array}$ & $\begin{array}{c}67 \text { GDM and } 74 \text { controls } \\
\text { (16-20, 20-24, and } 24-28 \\
\text { weeks gestation) }\end{array}$ & Not reported & Serum & qRT-PCR & $\begin{array}{l}\text { miR-183, miR-200b, } \\
\text { miR-125b, miR-1290 }\end{array}$ & - & - & $\begin{array}{c}\text { Cel-miR-39 } \\
\text { (exogenous control) }\end{array}$ \\
\hline
\end{tabular}

GDM—gestational diabetes mellitus; qRT-PCR—quantitative real-time PCR. 
Zhu et al. used high-throughput sequencing and qRT-PCR to investigate miRNAs in pooled plasma samples of Chinese women with $(n=10)$ or without $(n=10)$ GDM between 16 and 19 weeks of gestation. Five miRNAs (miR-16, miR-17, miR-19a, miR-19b, and miR-20a) were significantly upregulated in GDM compared to controls [139]. Bioinformatic analysis revealed that the targets of these miRNAs are associated with mitogen-activated protein kinase (MAPK), insulin, transforming growth factor beta (TGF- $\beta$ ), and mammalian target of rapamycin (mTOR) signaling pathways, providing insight into the role of these miRNAs in GDM. Cao et al. investigated miR-16, miR-17, and miR-20a in a larger cohort of Chinese women at 16-19 weeks, 20-24 weeks, and 24-28 week of gestation and found sustained increased expression in the plasma of women with GDM $(n=85)$ compared to controls $(n=72)$ at all the measured time points. However, they did not observe differences in the expressions of miR-19a and miR-19b [140], as previously reported by Zhu et al. More recently, Pheiffer et al. reported conflicting results. The expression of all five miRNAs were decreased in South African women with GDM; however, only the decreased expression of miR-20a was statistically significant [5].

Functional analyses of these miRNAs provided support for their role in the development of GDM [141-144]. Many other miRNAs were reported to exhibit altered expression during GDM, although these were identified in single studies only (Table 3).

\subsection{Limitations of Circulating microRNA Profiling}

The studies reviewed above highlight several miRNA candidates as biomarkers for GDM. However, the results are often discordant, possibly due to the different sample types and sizes, gestational age, and the methods of analysis used.

Differences in miRNA expression were reported in serum and plasma, suggesting that factors during the coagulation process could influence expression [145]. Currently, there is no consensus on the best quantification method to use when profiling circulating miRNAs. Different methods of quantification are known to vary in sensitivity and specificity [146], which may impact the accuracy and interpretation of the data. Moreover, data normalization presents a significant challenge for the analysis of circulating miRNA profiling. Although strategies using exogenous miRNAs such as C. elegans miR-39 were proven to be less variable than endogenous reference genes, no ideal normalization strategy exists [147]. Thus, standardized guidelines for miRNA profiling would aid in the biological interpretation of miRNA data.

\section{Current Perspectives and Future Recommendations}

Advances in molecular biology resulted in the identification of several molecular biomarkers for disease. Of these genetic variants, DNA methylation and miRNAs are widely studied during GDM [148-150]. These molecular markers are stably expressed in biological fluids and hold potential as diagnostic or prognostic biomarkers of GDM. As reviewed above, many studies provided evidence to support the use of these markers as biomarkers of GDM. However, despite these favorable results, molecular biomarkers face many challenges, which hinder their candidacy as biomarkers, and that must be addressed before they can be used clinically. As outlined above, SNPs, DNA methylation, and miRNAs are all impacted by ethnicity and environmental factors. Furthermore, technical challenges during analysis contribute to inaccurate data and lack of reproducibility. Thus, standardization of analytical methods is critical when profiling molecular biomarkers. Moreover, large prospective cohort studies, conducted in populations with different ethnicities and environmental factors, are warranted to identify robust markers that are not influenced by these factors. The ideal biomarker for GDM would most likely be a combination of several molecular biomarkers to overcome the lack of sensitivity and specificity of individual factors. For example, a single miRNA regulates up to 200 different genes [151]; thus, miRNAs found to be associated with GDM are non-specific and may possibly be involved in other conditions as well. To increase the predictive power of molecular biomarkers, future studies should consider using a combination of these markers in risk stratification models for predicting GDM risk. 


\section{Conclusions}

GDM is a growing public health problem worldwide. The short- and long-term consequences of GDM are likely to have an immediate negative impact on health systems, and , in addition, present a major reservoir of future disease. Screening and treatment of GDM leads to improved pregnancy outcomes [13]; thus, universal screening is widely advocated as a strategy to prevent adverse consequences. A growing body of evidence supports the use of SNPs, DNA methylation, and miRNAs as biomarkers that could aid in the early detection of GDM, thus facilitating intervention strategies to better manage GDM and improve health outcomes. Despite their potential, these molecular biomarkers face several challenges that need to be addressed before they can become clinically applicable. However, rapid technological advances could overcome these challenges and lead to the development of a quick, cost-effective point-of-care test that could accurately identify women at high risk for GDM during early pregnancy. The establishment of an international body to standardize analytical conditions for molecular biomarkers, and large prospective cohort studies in different populations are required.

Author Contributions: Conceptualization, S.D. and C.P. Writing-original draft preparation, S.D. and C.P. Writing-review and editing, S.D., C.P., and Y.A. S.D., C.P., Y.A., P.R., and S.A reviewed and approved the final manuscript.

Funding: This research received no external funding.

Conflicts of Interest: The authors declare no conflicts of interest.

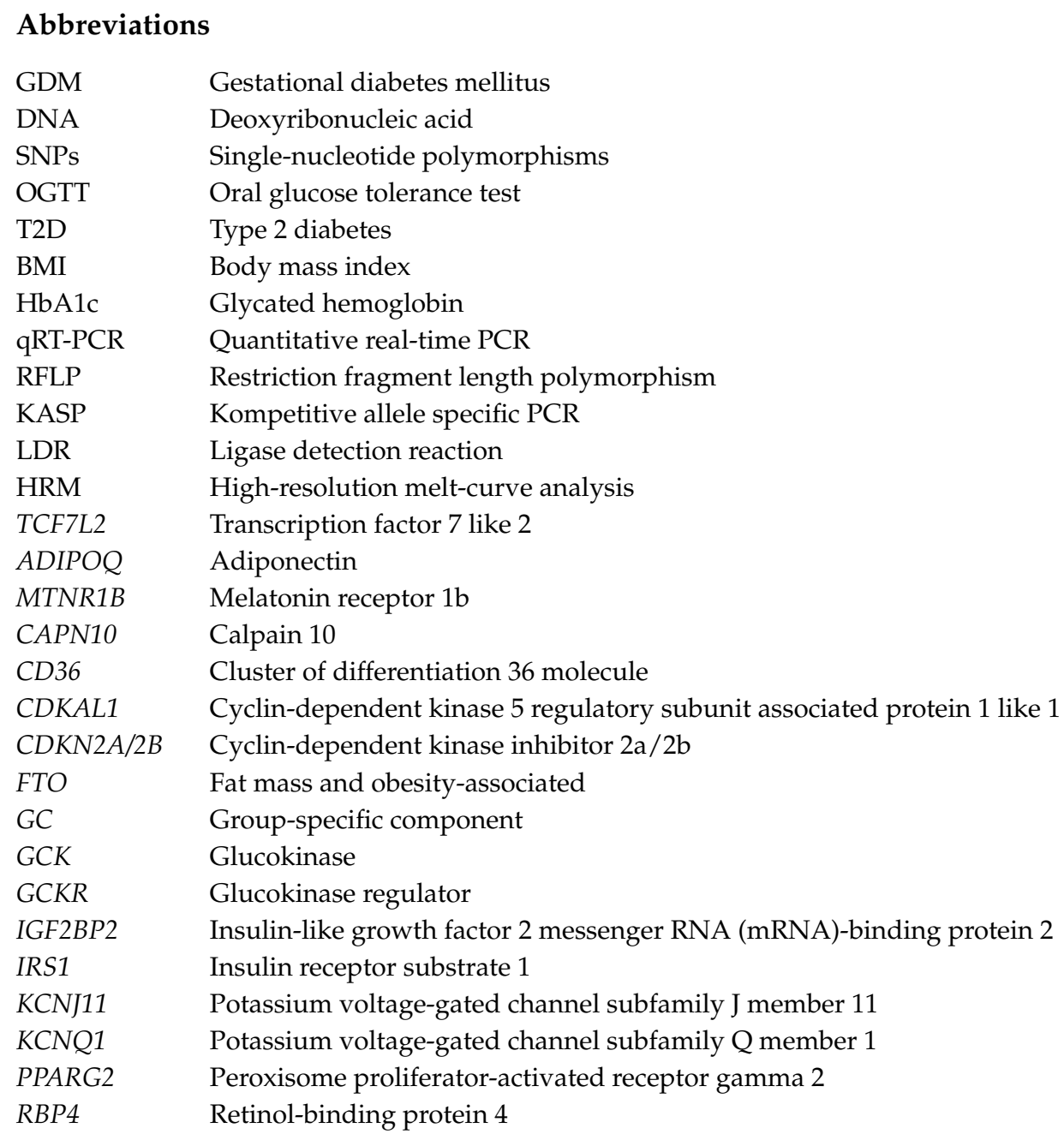


SLC30A8 Solute carrier family 30 member 8

STK11 Serine/threonine kinase 11

VDR Vitamin D receptor

CDC123 Cell division cycle 123 homolog

CAMK1D Calmodulin-dependent protein kinase 1D

MIF Macrophage migration inhibitory factor

DNMT DNA methyltransferase

TET Ten-eleven translocation

IL-10 Interleukin-10

IL-6 Interleukin-6

COPS8 Constitutive photomorphogenic homolog subunit 8

PIK3R5 Phosphoinositide 3-kinase regulatory subunit 5

HAAO 3-hydroxyanthranilate 3,4-dioxygenase

CCDC124 Coiled-coil domain containing 124

C5orf34 Chromosome 5 open reading frame 34

UTR Untranslated region

mRNA Messenger RNA

NPM1 Nucleophosphin 1

MAPK Mitogen-activated protein kinase

TGF- $\beta \quad$ Transforming growth factor beta

mTOR Mammalian target of rapamycin

\section{Appendix A}

Table A1. Search terms, including gestational diabetes mellitus, blood, single-nucleotide polymorphism, DNA methylation, and microRNAs, and corresponding synonyms searched.

\begin{tabular}{|c|c|}
\hline Concept 1: & Synonyms to be searched \\
\hline \multirow{7}{*}{ Gestational diabetes mellitus } & Gestational diabetes mellitus \\
\hline & Hyperglycemia during pregnancy \\
\hline & Diabetes of pregnancy \\
\hline & Glucose intolerance during pregnancy \\
\hline & Maternal hyperglycemia \\
\hline & Maternal hyperglycaemia \\
\hline & Diabetes during pregnancy \\
\hline Concept 2: & Synonyms to be searched \\
\hline \multirow{6}{*}{ microRNAs } & MicroRNAs or miRNAs \\
\hline & Circulating microRNAs or miRNAs \\
\hline & Circulating miRNAs \\
\hline & Cell free microRNAs or miRNAs \\
\hline & Small non-coding RNAs \\
\hline & Circulating biomarkers \\
\hline Concept 3: & Synonyms to be searched \\
\hline \multirow{3}{*}{ DNA methylation } & Global DNA methylation \\
\hline & Gene-specific DNA methylation \\
\hline & Genome-wide DNA methylation \\
\hline Concept 4: & Synonyms to be searched \\
\hline \multirow{4}{*}{ SNP } & Single-nucleotide polymorphisms \\
\hline & SNP genotyping \\
\hline & Genetic DNA variation \\
\hline & Genetic variants \\
\hline Concept 5: & Synonyms to be searched \\
\hline \multirow{7}{*}{ Biological markers } & Whole blood \\
\hline & Peripheral blood mononuclear cells (PMBCs) \\
\hline & PMBCs \\
\hline & Blood \\
\hline & Serum \\
\hline & Plasma \\
\hline & Maternal blood \\
\hline
\end{tabular}




\section{References}

1. WHO. Definition, Diagnosis and Classification of Diabetes Mellitus and Its Complications; World Health Organization: Geneva, Switzerland, 1999. Available online: http://apps.who.int/iris/handle/10665/66040 (accessed on 12 January 2018).

2. International Diabetes Federation. IDF Diabetes Atlas-Across the Globe. 2017. Available online: http:/ / diabetesatlas.org/across-the-globe.html (accessed on 6 July 2018).

3. International Association of Diabetes and Pregnancy Study Groups Consensus Panel; Metzger, B.E.; Gabbe, S.G.; Persson, B.; Buchanan, T.A.; Catalano, P.A.; Damm, P.; Dyer, A.R.; Leive, A.; Hod, M.; et al. International association of diabetes and pregnancy study groups recommendations on the diagnosis and classification of hyperglycemia in pregnancy. Diabetes Care 2010, 33, 676-682.

4. Wu, L.; Cui, L.; Tam, W.H.; Ma, R.C.W.; Wang, C.C. Genetic variants associated with gestational diabetes mellitus: A meta-analysis and subgroup analysis. Sci. Rep. 2016, 6, 30539. [CrossRef] [PubMed]

5. Pheiffer, C.; Dias, S.; Rheeder, P.; Adam, S. Decreased Expression of Circulating miR-20a-5p in South African Women with Gestational Diabetes Mellitus. Mol. Diagn. Ther. 2018, 22, 345-352. [CrossRef] [PubMed]

6. Barbour, L.A.; McCurdy, C.E.; Hernandez, T.L.; Kirwan, J.P.; Catalano, P.M.; Friedman, J.E. Cellular Mechanisms for Insulin Resistance in Normal Pregnancy and Gestational Diabetes. Diabetes Care 2007, 30 (Suppl. S2), S112-S119. [CrossRef] [PubMed]

7. Young, B.C.; Ecker, J.L. Fetal macrosomia and shoulder dystocia in women with gestational diabetes: Risks amenable to treatment? Curr. Diabetes Rep. 2013, 13, 12-18. [CrossRef] [PubMed]

8. Mohammadbeigi, A.; Farhadifar, F.; Zadeh, N.S.; Mohammadsalehi, N.; Rezaiee, M.; Aghaei, M. Fetal macrosomia: Risk factors, maternal, and perinatal outcome. Ann. Med. Health Sci. Res. 2013, 3, 546-550. [PubMed]

9. Alam, M.; Raza, S.J.; Sherali, A.R.; Akhtar, A.S.M.; Akhtar, S.M. Neonatal complications in infants born to diabetic mothers. J. Coll. Phys. Surg. Pak. 2006, 16, 212-215.

10. Mitanchez, D.; Yzydorczyk, C.; Siddeek, B.; Boubred, F.; Benahmed, M.; Simeoni, U. The offspring of the diabetic mother-short- and long-term implications. Best Prac. Res. Clin. Obstet. Gynaecol. 2015, 29, $256-269$. [CrossRef] [PubMed]

11. Garcia-Vargas, L.; Addison, S.S.; Nistala, R.; Kurukulasuriya, D.; Sowers, J.R. Gestational Diabetes and the Offspring: Implications in the Development of the Cardiorenal Metabolic Syndrome in Offspring. Cardiorenal Med. 2012, 2, 134-142. [CrossRef] [PubMed]

12. Kim, C.; Newton, K.M.; Knopp, R.H. Gestational diabetes and the incidence of type 2 diabetes: A systematic review. Diabetes Care 2002, 25, 1862-1868. [CrossRef] [PubMed]

13. Duran, A.; Sáenz, S.; Torrejón, M.J.; Bordiú, E.; Del Valle, L.; Galindo, M.; Perez, N.; Herraiz, M.A.; Izquierdo, N.; Rubio, M.A.; et al. Introduction of IADPSG criteria for the screening and diagnosis of gestational diabetes mellitus results in improved pregnancy outcomes at a lower cost in a large cohort of pregnant women: The St. Carlos Gestational Diabetes Study. Diabetes Care 2014, 37, 2442-2450. [CrossRef] [PubMed]

14. McIntyre, H.D.; Colagiuri, S.; Roglic, G.; Hod, M. Diagnosis of GDM: A suggested consensus. Best Prac. Res. Clin. Obstet. Gynaecol. 2015, 29, 194-205. [CrossRef] [PubMed]

15. Adam, S.; Rheeder, P. Screening for gestational diabetes mellitus in a South African population: Prevalence, comparison of diagnostic criteria and the role of risk factors. S. Afr. Med. J. 2017, 107, 523-527. [CrossRef] [PubMed]

16. Zhang, C.; Rawal, S.; Chong, Y.S. Risk factors for gestational diabetes: Is prevention possible? Diabetologia 2016, 59, 1385-1390. [CrossRef] [PubMed]

17. Miailhe, G.; Kayem, G.; Girard, G.; Legardeur, H.; Mandelbrot, L. Selective rather than universal screening for gestational diabetes mellitus? Eur. J. Obstet. Gynecol. Reprod. Boil. 2015, 191, 95-100. [CrossRef] [PubMed]

18. Smirnakis, K.V.; Plati, A.; Wolf, M.; Thadhani, R.; Ecker, J.L. Predicting gestational diabetes: Choosing the optimal early serum marker. Am. J. Obstet. Gynecol. 2007, 196, 410.e1-410.e7. [CrossRef] [PubMed]

19. Nanda, S.; Savvidou, M.; Syngelaki, A.; Akolekar, R.; Nicolaides, K.H. Prediction of gestational diabetes mellitus by maternal factors and biomarkers at 11 to 13 weeks. Prenat. Diagn. 2011, 31, 135-141. [CrossRef] [PubMed] 
20. Rasanen, J.P.; Snyder, C.K.; Rao, P.V.; Mihalache, R.; Heinonen, S.; Gravett, M.G.; Roberts, C.T.; Nagalla, S.R. Glycosylated fibronectin as a first-trimester biomarker for prediction of gestational diabetes. Obstet. Gynecol. 2013, 122, 586-594. [CrossRef] [PubMed]

21. Renz, P.B.; Cavagnolli, G.; Weinert, L.S.; Silveiro, S.P.; Camargo, J.L. HbA1c Test as a Tool in the Diagnosis of Gestational Diabetes Mellitus. PLoS ONE 2015, 10, e0135989. [CrossRef] [PubMed]

22. Zhang, C.; Bao, W.; Rong, Y.; Yang, H.; Bowers, K.; Yeung, E.; Kiely, M. Genetic variants and the risk of gestational diabetes mellitus: A systematic review. Hum. Reprod. Update 2013, 19, 376-390. [CrossRef] [PubMed]

23. Haertle, L.; El Hajj, N.; Dittrich, M.; Müller, T.; Nanda, I.; Lehnen, H.; Haaf, T. Epigenetic signatures of gestational diabetes mellitus on cord blood methylation. Clin. Epigenet. 2017, 9, 28. [CrossRef] [PubMed]

24. Guarino, E.; Poggi, C.D.; Grieco, G.E.; Cenci, V.; Ceccarelli, E.; Crisci, I.; Sebastiani, G.; Dotta, F. Circulating MicroRNAs as biomarkers of gestational diabetes mellitus: Updates and perspectives. Int. J. Endocrinol. 2018. [CrossRef]

25. Strimbu, K.; Tavel, J.A. What are Biomarkers? Curr. Opin. HIV AIDS 2010, 5, 463-466. [CrossRef] [PubMed]

26. Sahu, P.; Pinkalwar, N.; Dubey, R.D.; Paroha, S.; Chatterjee, S.; Chatterjee, T. Biomarkers: An emerging tool for diagnosis of a disease and drug development. Asian J. Res. Pharm. Sci. 2011, 1, 9-16.

27. Etheridge, A.; Lee, I.; Hood, L.; Galas, D.; Wang, K. Extracellular microRNA: A new source of biomarkers. Mutat. Res. 2011, 717, 85-90. [CrossRef] [PubMed]

28. Standards for clinical use of genetic variants. Nat. Genet. 2014, 46, 93. [CrossRef] [PubMed]

29. Mikeska, T.; Craig, J.M. DNA Methylation Biomarkers: Cancer and Beyond. Genes 2014, 5, 821-864. [CrossRef] [PubMed]

30. Hydbring, P.; Badalian-Very, G. Clinical applications of microRNAs. F1000Research 2013. [CrossRef]

31. The International HapMap Consortium. A second generation human haplotype map of over 3.1 million SNPs. Nature 2007, 449, 851-861. [CrossRef] [PubMed]

32. Sachidanandam, R.; Weissman, D.; Schmidt, S.C.; Kakol, J.M.; Stein, L.D.; Marth, G.; Sherry, S.; Mullikin, J.C.; Mortimore, B.J.; Willey, D.L.; et al. A map of human genome sequence variation containing 1.42 million single nucleotide polymorphisms. Nature 2001, 409, 928-933. [PubMed]

33. McCarthy, M.I. Genomics, type 2 diabetes, and obesity. N. Engl. J. Med. 2010, 363, 2339-2350. [CrossRef] [PubMed]

34. Rankinen, T.; Zuberi, A.; Chagnon, Y.C.; Weisnagel, S.J.; Argyropoulos, G.; Walts, B.; Pérusse, L.; Bouchard, C. The human obesity gene map: The 2005 update. Obesity 2006, 14, 529-644. [CrossRef] [PubMed]

35. Morris, A.P.; Voight, B.F.; Teslovich, T.M.; Ferreira, T.; Segrè, A.V.; Steinthorsdottir, V.; Strawbridge, R.J.; Khan, H.; Grallert, H.; Mahajan, A.; et al. Large-scale association analysis provides insights into the genetic architecture and pathophysiology of type 2 diabetes. Nat. Genet. 2012, 44, 981-990. [PubMed]

36. Hattersley, A.T. Prime suspect: The TCF7L2 gene and type 2 diabetes risk. J. Clin. Investig. 2007, 117, 2077-2079. [CrossRef] [PubMed]

37. Ding, M.; Chavarro, J.; Olsen, S.; Lin, Y.; Ley, S.H.; Bao, W.; Rawal, S.; Grunnet, L.G.; Thuesen, A.C.B.; Mills, J.L.; et al. Genetic variants of gestational diabetes mellitus: A study of 112 SNPs among 8722 women in two independent populations. Diabetologia 2018, 61, 1758-1768. [CrossRef] [PubMed]

38. Franzago, M.; Fraticelli, F.; Marchetti, D.; Celentano, C.; Liberati, M.; Stuppia, L.; Vitacolonna, E. Nutrigenetic variants and cardio-metabolic risk in women with or without gestational diabetes. Diabetes Res. Clin. Prac. 2018, 137, 64-71. [CrossRef] [PubMed]

39. Popova, P.V.; Klyushina, A.A.; Vasilyeva, L.B.; Tkachuk, A.S.; Bolotko, Y.A.; Gerasimov, A.S.; Pustozerov, E.A.; Kravchuk, E.N.; Predeus, A.; Kostareva, A.A.; et al. Effect of gene-lifestyle interaction on gestational diabetes risk. Oncotarget 2017, 8, 112024-112035. [CrossRef] [PubMed]

40. Michalak-Wojnowska, M.; Gorczyca-Siudak, D.; Gorczyca, T.; Mosiewicz, B.; Kwaśniewska, A.; Filip, A.; Mosiewicz, J. Association between rs7901695 and rs7903146 polymorphisms of the TCF7L2 gene and gestational diabetes in the population of Southern Poland. Ginekol. Polska 2016, 87, 745-750. [CrossRef] [PubMed]

41. Pagán, A.; Sabater-Molina, M.; Olza, J.; Prieto-Sánchez, M.T.; Blanco-Carnero, J.E.; Parrilla, J.J.; Gil, A.; Larqué, E. A gene variant in the transcription factor 7-like 2 (TCF7L2) is associated with an increased risk of gestational diabetes mellitus. Eur. J. Obstet. Gynecol. Reprod. Boil. 2015, 180, 77-82. [CrossRef] [PubMed] 
42. Reyes-López, R.; Pérez-Luque, E.; Malacara, J.M. Metabolic, hormonal characteristics and genetic variants of TCF7L2 associated with development of gestational diabetes mellitus in Mexican women. Diabetes/Metab. Res. Rev. 2014, 30, 701-706. [CrossRef] [PubMed]

43. Papadopoulou, A.; Lynch, K.F.; Shaat, N.; Håkansson, R.; Ivarsson, S.A.; Berntorp, K.; Agardh, C.D.; Lernmark, A. Gestational diabetes mellitus is associated with TCF7L2 gene polymorphisms independent of HLA-DQB1*0602 genotypes and islet cell autoantibodies. Diabet. Med. 2011, 28, 1018-1027. [CrossRef] [PubMed]

44. Huopio, H.; Hakkarainen, H.; Pääkkönen, M.; Kuulasmaa, T.; Heinonen, S.; Laakso, M. Association of risk variants for type 2 diabetes and hyperglycemia with gestational diabetes. Eur. J. Endocrinol. 2013, 169, 291-297. [CrossRef] [PubMed]

45. Anghebem-Oliveira, M.I.; Martins, B.R.; Alberton, D.; de Souza Ramos, E.A.; Picheth, G.; Rego, F.G.M. Type 2 diabetes-associated genetic variants of FTO, LEPR, PPARg, and TCF712 in gestational diabetes in a Brazilian population. Arch. Endocrinol. Metab. 2017, 61, 238-248. [CrossRef] [PubMed]

46. Stuebe, A.; Wise, A.; Nguyen, T.; Herring, A.; North, K.; Siega-Riz, A. Maternal Genotype and Gestational Diabetes. Am. J. Perinatol. 2013, 31, 069-076. [CrossRef]

47. de Melo, S.F.; Frigeri, H.R.; dos Santos-Weiss, I.C.R.; Réa, R.R.; de Souza, E.M.; Alberton, D.; de Moraes Rego, F.G.; Picheth, G. Polymorphisms in FTO and TCF7L2 genes of Euro-Brazilian women with gestational diabetes. Clin. Biochem. 2015, 48, 1064-1067. [CrossRef] [PubMed]

48. Pilgaard, K.; Jensen, C.B.; Schou, J.H.; Lyssenko, V.; Wegner, L.; Brøns, C.; Vilsbøll, T.; Hansen, T.; Madsbad, S.; Holst, J.J.; et al. The T allele of rs7903146 TCF7L2 is associated with impaired insulinotropic action of incretin hormones, reduced $24 \mathrm{~h}$ profiles of plasma insulin and glucagon, and increased hepatic glucose production in young healthy men. Diabetologia 2009, 52, 1298-1307. [CrossRef] [PubMed]

49. Bouchard, L.; Hivert, M.-F.; Guay, S.-P.; St-Pierre, J.; Perron, P.; Brisson, D. Placental adiponectin gene DNA methylation levels are associated with mothers' blood glucose concentration. Diabetes 2012, 61, 1272-1280. [CrossRef] [PubMed]

50. Bao, W.; Baecker, A.; Song, Y.; Kiely, M.; Liu, S.; Zhang, C. Adipokine levels during the first or early second trimester of pregnancy and subsequent risk of gestational diabetes mellitus: A systematic review. Metabolism 2015, 64, 756-764. [CrossRef] [PubMed]

51. Pawlik, A.; Teler, J.; Maciejewska, A.; Sawczuk, M.; Safranow, K.; Dziedziejko, V. Adiponectin and leptin gene polymorphisms in women with gestational diabetes mellitus. J. Assist. Reprod. Genet. 2017, 34, 511-516. [CrossRef] [PubMed]

52. Beltcheva, O.; Boyadzhieva, M.; Angelova, O.; Mitev, V.; Kaneva, R.; Atanasova, I. The rs266729 single-nucleotide polymorphism in the adiponectin gene shows association with gestational diabetes. Arch. Gynecol. Obstet. 2014, 289, 743-748. [CrossRef] [PubMed]

53. Takhshid, M.A.; Haem, Z.; Aboualizadeh, F. The association of circulating adiponectin and + $45 \mathrm{~T} / \mathrm{G}$ polymorphism of adiponectin gene with gestational diabetes mellitus in Iranian population. J. Diabetes Metab. Disord. 2015, 14, 30. [CrossRef] [PubMed]

54. Low, C.F.; Mohd Tohit, E.R.; Chong, P.P.; Idris, F. Adiponectin SNP45TG is associated with gestational diabetes mellitus. Arch. Gynecol. Obstet. 2011, 283, 1255-1260. [CrossRef] [PubMed]

55. Han, Y.; Zheng, Y.-L.; Fan, Y.-P.; Liu, M.-H.; Lu, X.-Y.; Tao, Q. Association of adiponectin gene polymorphism 45TG with gestational diabetes mellitus diagnosed on the new IADPSG criteria, plasma adiponectin levels and adverse pregnancy outcomes. Clin. Exp. Med. 2014, 15, 47-53. [CrossRef] [PubMed]

56. Sun, H.; Wang, X.; Chen, J.; Gusdon, A.M.; Song, K.; Li, L.; Qu, S. Melatonin Treatment Improves Insulin Resistance and Pigmentation in Obese Patients with Acanthosis Nigricans. Int. J. Endocrinol. 2018. [CrossRef] [PubMed]

57. Tarnowski, M.; Malinowski, D.; Safranow, K.; Dziedziejko, V.; Pawlik, A. MTNR1A and MTNR1B gene polymorphisms in women with gestational diabetes. Gynecol. Endocrinol. 2017, 33, 395-398. [CrossRef] [PubMed]

58. Rosta, K.; Al-Aissa, Z.; Hadarits, O.; Harreiter, J.; Nádasdi, A.; Kelemen, F.; Bancher-Todesca, D.; Komlósi, Z.; Németh, L.; Rigó, J.; et al. Association study with 77 SNPs confirms the robust role for the rs10830963/G of MTNR1B variant and identifies two novel associations in gestational diabetes mellitus development. PLoS ONE 2017, 12, e0169781. [CrossRef] [PubMed] 
59. Li, C.; Zhou, Y.; Qiao, B.; Xu, L.; Li, Y.; Li, C. Association Between a Melatonin Receptor 1B Genetic Polymorphism and Its Protein Expression in Gestational Diabetes Mellitus. Reprod. Sci. 2018. [CrossRef] [PubMed]

60. Kim, J.Y.; Cheong, H.S.; Park, B.-J.; Baik, S.H.; Park, S.; Lee, S.W.; Kim, M.H.; Chung, J.H.; Choi, J.S.; Kim, M.Y.; et al. Melatonin receptor $1 \mathrm{~B}$ polymorphisms associated with the risk of gestational diabetes mellitus. BMC Med. Genet. 2011, 12, 82. [CrossRef] [PubMed]

61. Wang, Y.; Nie, M.; Li, W.; Ping, F.; Hu, Y.; Ma, L.; Gao, J.; Liu, J. Association of six single nucleotide polymorphisms with gestational diabetes mellitus in a chinese population. PLOS ONE 2011, 6, e26953. [CrossRef] [PubMed]

62. Prokopenko, I.; Langenberg, C.; Florez, J.C.; Saxena, R.; Soranzo, N.; Thorleifsson, G.; Loos, R.J.; Manning, A.K.; Jackson, A.U.; Aulchenko, Y.; et al. Variants in MTNR1B influence fasting glucose levels. Nat. Genet. 2009, 41, 77-81. [CrossRef] [PubMed]

63. Iynedjian, P.B. Molecular physiology of mammalian glucokinase. Cell Mol. Life Sci. 2009, 66, 27-42. [CrossRef] [PubMed]

64. Han, X.; Cui, H.; Chen, X.; Xie, W.; Chang, Y. Association of the glucokinase gene promoter polymorphism -30G > A (rs1799884) with gestational diabetes mellitus susceptibility: A case-control study and meta-analysis. Arch. Gynecol. Obstet. 2015, 292, 291-298. [CrossRef] [PubMed]

65. Tarnowski, M.; Malinowski, D.; Pawlak, K.; Dziedziejko, V.; Safranow, K.; Pawlik, A. GCK, GCKR, FADS1, DGKB/TMEM195 and CDKAL1 Gene Polymorphisms in Women with Gestational Diabetes. Can. J. Diabetes 2017, 41, 372-379. [CrossRef] [PubMed]

66. Jamalpour, S.; Zain, S.M.; Mosavat, M.; Mohamed, Z.; Omar, S.Z. A case-control study and meta-analysis confirm glucokinase regulatory gene rs780094 is a risk factor for gestational diabetes mellitus. Gene 2018, 650, 34-40. [CrossRef] [PubMed]

67. Anghebem-Oliveira, M.I.; Webber, S.; Alberton, D.; de Souza, E.M.; Klassen, G.; Picheth, G.; Rego, F.G.D.M. The GCKR Gene Polymorphism rs780094 is a Risk Factor for Gestational Diabetes in a Brazilian Population. J. Clin. Lab. Anal. 2017, 31, e22035. [CrossRef] [PubMed]

68. Wang, H.; Dong, S.; Xu, H.; Qian, J.; Yang, J. Genetic variants in FTO associated with metabolic syndrome: A meta- and gene-based analysis. Mol. Boil. Rep. 2012, 39, 5691-5698. [CrossRef] [PubMed]

69. Merkestein, M.; Sellayah, D. Role of FTO in Adipocyte Development and Function: Recent Insights. Int. J. Endocrinol. 2015. [CrossRef] [PubMed]

70. Saucedo, R.; Valencia, J.; Gutierrez, C.; Basurto, L.; Hernandez, M.; Puello, E.; Rico, G.; Vega, G.; Zarate, A. Gene variants in the FTO gene are associated with adiponectin and TNF-alpha levels in gestational diabetes mellitus. Diabetol. Metab. Syndr. 2017, 9, 32. [CrossRef] [PubMed]

71. Gual, P.; Le Marchand-Brustel, Y.; Tanti, J.-F. Positive and negative regulation of insulin signaling through IRS-1 phosphorylation. Biochimie 2005, 87, 99-109. [CrossRef] [PubMed]

72. Alharbi, K.K.; Khan, I.A.; Abotalib, Z.; Al-Hakeem, M.M. Insulin receptor substrate-1 (IRS-1) Gly927Arg: Correlation with gestational diabetes mellitus in Saudi women. BioMed. Res. Int. 2014. [CrossRef] [PubMed]

73. Yasuda, K.; Miyake, K.; Horikawa, Y.; Hara, K.; Osawa, H.; Furuta, H.; Hirota, Y.; Mori, H.; Jonsson, A.; Sato, Y.; et al. Variants in KCNQ1 are associated with susceptibility to type 2 diabetes mellitus. Nat. Genet. 2008, 40, 1092-1097. [CrossRef] [PubMed]

74. Fatima, S.S.; Chaudhry, B.; Khan, T.A.; Farooq, S. KCNQ1 rs2237895 polymorphism is associated with gestational diabetes in Pakistani women. Pak. J. Med. Sci. 2016, 32, 1380-1385. [CrossRef] [PubMed]

75. Kwak, S.H.; Kim, T.H.; Cho, Y.M.; Choi, S.H.; Jang, H.C.; Park, K.S. Polymorphisms in KCNQ1 are associated with gestational diabetes in a Korean population. Horm. Res. Paediatr. 2010, 74, 333-338. [CrossRef] [PubMed]

76. Ao, D.; Wang, H.-J.; Wang, L.-F.; Song, J.-Y.; Yang, H.-X.; Wang, Y. The rs2237892 polymorphism in KCNQ1 influences gestational diabetes mellitus and glucose levels: A case-control study and meta-analysis. PLoS ONE 2015, 10, e0128901. [CrossRef] [PubMed]

77. Flannick, J.; Thorleifsson, G.; Beer, N.L.; Jacobs, S.B.R.; Grarup, N.; Burtt, N.P.; Mahajan, A.; Fuchsberger, C.; Atzmon, G.; Benediktsson, R.; et al. Loss-of-function mutations in SLC30A8 protect against type 2 diabetes. Nat. Genet. 2014, 46, 357-363. [CrossRef] [PubMed]

78. Dereke, J.; Palmqvist, S.; Nilsson, C.; Landin-Olsson, M.; Hillman, M. The prevalence and predictive value of the SLC30A8 R325W polymorphism and zinc transporter 8 autoantibodies in the development of GDM and postpartum type 1 diabetes. Endocrine 2016, 53, 740-746. [CrossRef] [PubMed] 
79. Welter, D.; MacArthur, J.; Morales, J.; Burdett, T.; Hall, P.; Junkins, H.; Klemm, A.; Flicek, P.; Manolio, T.; Hindorff, L.; et al. The NHGRI GWAS Catalog, a curated resource of SNP-trait associations. Nucleic Acids Res. 2014, 42, D1001-D1006. [CrossRef] [PubMed]

80. Andraweera, P.H.; Gatford, K.L.; Dekker, G.A.; Leemaqz, S.; Jayasekara, R.W.; Dissanayake, V.H.W.; McCowan, L.; Roberts, C.T. The INSR rs2059806 single nucleotide polymorphism, a genetic risk factor for vascular and metabolic disease, associates with pre-eclampsia. Reprod. BioMed. Online 2017, 34, 392-398. [CrossRef] [PubMed]

81. Noury, A.E.; Azmy, O.; Alsharnoubi, J.; Salama, S.; Okasha, A.; Gouda, W. Variants of CDKAL1 rs7754840 (G/C) and CDKN2A/2B rs10811661 (C/T) with gestational diabetes: Insignificant association. BMC Res. Notes 2018, 11, 181. [CrossRef] [PubMed]

82. Castro-Martínez, A.G.; Sánchez-Corona, J.; Vázquez-Vargas, A.P.; García-Zapién, A.G.; López-Quintero, A.; Villalpando-Velazco, H.J.; Flores-Martínez, S.E. Association analysis of calpain 10 gene variants/haplotypes with gestational diabetes mellitus among Mexican women. Cell. Mol. Boil. 2018, 6, 81-86. [CrossRef] [PubMed]

83. Leipold, H.; Knöfler, M.; Gruber, C.; Haslinger, P.; Bancher-Todesca, D.; Worda, C. Calpain-10 haplotype combination and association with gestational diabetes mellitus. Obstet. Gynecol. 2004, 103, 1235-1240. [CrossRef] [PubMed]

84. Lenin, M.; Ramasamy, R.; Kulkarani, S.; Ghose, S.; Srinivasan, A.R.S. Association of KCNJ11(RS5219) gene polymorphism with biochemical markers of glycemic status and insulin resistance in gestational diabetes mellitus. Meta Gene 2018, 16, 134-138.

85. Saucedo, R.; Zarate, A.; Basurto, L.; Hernandez, M.; Puello, E.; Mendoza-Lorenzo, P.; Ostrosky-Wegman, P. RBP4 gene variants are associated with insulin resistance in women with previous gestational diabetes. Dis. Markers 2014. [CrossRef] [PubMed]

86. Ping, F.; Xiang, H.-D.; Li, M.; Li, W.; Liu, J.-T.; Nie, M.; Hui, Y.-C. Effects of variation in retinol binding protein 4 gene and adipose specific expression of gestational diabetes in Beijing, China. Diabetes Res. Clin. Prac. 2012, 97, 283-289. [CrossRef] [PubMed]

87. Hiraoka, M.; Urschitz, J.; Sultan, O.; Ward, K. A polymorphism in the retinol binding protein 4 gene is not associated with gestational diabetes mellitus in several different ethnic groups. Hawaii Med. J. 2011, 70, 164-167. [PubMed]

88. Shi, A.; Wen, J.; Liu, G.; Liu, H.; Fu, Z.; Zhou, J.; Zhu, Y.; Liu, Y.; Guo, X.; Xu, J. Genetic variants in vitamin D signaling pathways and risk of gestational diabetes mellitus. Oncotarget 2016, 7, 67788-67795. [CrossRef] [PubMed]

89. Wang, Y.; Wang, O.; Li, W.; Ma, L.; Ping, F.; Chen, L.; Nie, M. Variants in Vitamin D binding protein gene are associated with gestational diabetes mellitus. Medicine 2015, 94, e1693. [CrossRef] [PubMed]

90. Alharbi, K.K.; Khan, I.A.; Eldesouky, M.H.; Al-Hakeem, M.M.; Abotalib, Z. The genetic polymorphism in the STK11 does not affect gestational diabetes. Acta Biochim. Pol. 2015, 62, 569-572. [CrossRef] [PubMed]

91. Bassols, J.; Megia, A.; Soriano-Rodríguez, P.; Díaz, M.; Prats-Puig, A.; Gifre, M.; Simón-Muela, I.; Torrent, S.; Borrel, A.C.; Riera-Socasau, J.C.; et al. A common gene variant in STK11 is associated with metabolic risk markers and diabetes during gestation. Fertil. Steril. 2013, 100, 788-792. [CrossRef] [PubMed]

92. Aslani, S.; Hossein-nezhad, A.; Maghbooli, Z.; Mirzaei, K.; Karimi, F. Genetic variation in macrophage migration inhibitory factor associated with gestational diabetes mellitus and metabolic syndrome. Horm. Metab. Res. 2011, 43, 557-561. [CrossRef] [PubMed]

93. Ye, D.; Fei, Y.; Ling, Q.; Xu, W.; Zhang, Z.; Shu, J.; Li, C.; Dong, F. Polymorphisms in TCF7L2 gene are associated with gestational diabetes mellitus in Chinese Han population. Sci. Rep. 2016, 6, 30686. [CrossRef] [PubMed]

94. Bartáková, V.; Kuricová, K.; Zlámal, F.; Bělobrádková, J.; Kaňková, K. Differences in food intake and genetic variability in taste receptors between Czech pregnant women with and without gestational diabetes mellitus. Eur. J. Nutr. 2018, 57, 513-521. [CrossRef] [PubMed]

95. Yang, Y.; Luo, B.R.; Hu, M.; Zhao, D.M.; Jing, W.J. Association of CD36 gene single nucleotide polymorphism with gestational diabetes mellitus in Chinese Han population. Clin. Exp. Obstet. Gynecol. 2018, 45, $266-271$.

96. Tarnowski, M.; Malinowski, D.; Safranow, K.; Dziedziejko, V.; Pawlik, A. CDC123/CAMK1D gene rs12779790 polymorphism and rs10811661 polymorphism upstream of the CDKN2A/2B gene in women with gestational diabetes. J. Perinatol. 2017, 37, 345-348. [CrossRef] [PubMed] 
97. Lim, D.H.K.; Maher, E.R. DNA methylation: A form of epigenetic control of gene expression. Obstet. Gynaecol. 2010, 12, 37-42. [CrossRef]

98. Bird, A. DNA methylation patterns and epigenetic memory. Genes Dev. 2002, 16, 6-21. [CrossRef] [PubMed]

99. Bird, A.P. DNA methylation and the frequency of CpG in animal DNA. Nucleic Acids Res. 1980, 8, 1499-1504. [CrossRef] [PubMed]

100. Wu, X.; Zhang, Y. TET-mediated active DNA demethylation: Mechanism, function and beyond. Nat. Rev. Genet. 2017, 18, 517-534. [CrossRef] [PubMed]

101. Pheiffer, C.; Erasmus, R.T.; Kengne, A.P.; Matsha, T.E. Differential DNA methylation of microRNAs within promoters, intergenic and intragenic regions of type 2 diabetic, pre-diabetic and non-diabetic individuals. Clin. Biochem. 2016, 49, 433-438. [CrossRef] [PubMed]

102. Van Dijk, S.J.; Molloy, P.L.; Varinli, H.; Morrison, J.L.; Muhlhausler, B.S. Members of EpiSCOPE. Epigenetics and human obesity. Int. J. Obes. 2015, 39, 85-97. [CrossRef] [PubMed]

103. Toperoff, G.; Aran, D.; Kark, J.D.; Rosenberg, M.; Dubnikov, T.; Nissan, B.; Wainstein, J.; Freidlander, Y.; Levy-Lahad, E.; Glaser, B.; et al. Genome-wide survey reveals predisposing diabetes type 2-related DNA methylation variations in human peripheral blood. Hum. Mol. Genet. 2012, 21, 371-383. [CrossRef] [PubMed]

104. Kim, M.; Long, T.I.; Arakawa, K.; Wang, R.; Yu, M.C.; Laird, P.W. DNA Methylation as a Biomarker for Cardiovascular Disease Risk. PLoS ONE 2010, 5, e9692. [CrossRef] [PubMed]

105. Houde, A.-A.; Guay, S.-P.; Desgagné, V.; Hivert, M.-F.; Baillargeon, J.-P.; St-Pierre, J.; Perron, P.; Gaudet, D.; Brisson, D.; Bouchard, L. Adaptations of placental and cord blood ABCA1 DNA methylation profile to maternal metabolic status. Epigenetics 2013, 8, 1289-1302. [CrossRef] [PubMed]

106. Finer, S.; Mathews, C.; Lowe, R.; Smart, M.; Hillman, S.; Foo, L.; Sinha, A.; Williams, D.; Rakyan, V.K.; Hitman, G.A. Maternal gestational diabetes is associated with genome-wide DNA methylation variation in placenta and cord blood of exposed offspring. Hum. Mol. Genet. 2015, 24, 3021-3029. [CrossRef] [PubMed]

107. Ruchat, S.-M.; Houde, A.-A.; Voisin, G.; St-Pierre, J.; Perron, P.; Baillargeon, J.-P.; Gaudet, D.; Hivert, M.-F.; Brisson, D.; Bouchard, L. Gestational diabetes mellitus epigenetically affects genes predominantly involved in metabolic diseases. Epigenetics 2013, 8, 935-943. [CrossRef] [PubMed]

108. Nomura, Y.; Lambertini, L.; Rialdi, A.; Lee, M.; Mystal, E.Y.; Grabie, M.; Manaster, I.; Huynh, N.; Finik, J.; Davey, M.; et al. Global methylation in the placenta and umbilical cord blood from pregnancies with maternal gestational diabetes, preeclampsia, and obesity. Reprod. Sci. 2014, 21, 131-137. [CrossRef] [PubMed]

109. Reichetzeder, C.; Dwi Putra, S.E.; Pfab, T.; Slowinski, T.; Neuber, C.; Kleuser, B.; Hocher, B. Increased global placental DNA methylation levels are associated with gestational diabetes. Clin. Epigenet. 2016, 8, 82. [CrossRef] [PubMed]

110. Pinney, S.E. Metabolic disorders and developmental origins of health and disease. In The Epigenome and Developmental Origins of Health and Disease; Elsevier: Amsterdam, The Netherlands, 2015; pp. 267-289.

111. Hajj, N.E.; Pliushch, G.; Schneider, E.; Dittrich, M.; Müller, T.; Korenkov, M.; Aretz, M.; Zechner, U.; Lehnen, H.; Haaf, T. Metabolic Programming of MEST DNA Methylation by Intrauterine Exposure to Gestational Diabetes Mellitus. Diabetes 2012, 120289. [CrossRef]

112. Chim, S.S.C.; Shing, T.K.F.; Hung, E.C.W.; Leung, T.-Y.; Lau, T.-K.; Chiu, R.W.K.; Lo, Y.M.D. Detection and characterization of placental microRNAs in maternal plasma. Clin. Chem. 2008, 54, 482-490. [CrossRef] [PubMed]

113. Kurdyukov, S.; Bullock, M. DNA Methylation Analysis: Choosing the Right Method. Biology 2016, 5, 3. [CrossRef] [PubMed]

114. Dias, S.; Adam, S.; Wyk, N.V.; Rheeder, P.; Louw, J.; Pheiffer, C. Global DNA methylation profiling in South African women with Gestational diabetes mellites. Biomarkers 2018. Accepted for publication with minor revisions.

115. Kang, J.; Lee, C.-N.; Li, H.-Y.; Hsu, K.-H.; Lin, S.-Y. Genome-wide DNA methylation variation in maternal and cord blood of gestational diabetes population. Diabetes Res. Clin. Prac. 2017, 132, 127-136. [CrossRef] [PubMed]

116. Enquobahrie, D.A.; Moore, A.; Muhie, S.; Tadesse, M.G.; Lin, S.; Williams, M.A. Early Pregnancy Maternal Blood DNA Methylation in Repeat Pregnancies and Change in Gestational Diabetes Mellitus Status-A Pilot Study. Reprod. Sci. 2015, 22, 904-910. [CrossRef] [PubMed] 
117. Wu, P.; Farrell, W.E.; Haworth, K.E.; Emes, R.D.; Kitchen, M.O.; Glossop, J.R.; Hanna, F.W.; Fryer, A.A. Maternal genome-wide DNA methylation profiling in gestational diabetes shows distinctive disease-associated changes relative to matched healthy pregnancies. Epigenetics 2018, 13, 122-128. [CrossRef] [PubMed]

118. Kang, J.; Lee, C.-N.; Li, H.-Y.; Hsu, K.-H.; Wang, S.-H.; Lin, S.-Y. Association of interleukin-10 methylation levels with gestational diabetes in a Taiwanese population. Front. Genet. 2018. [CrossRef] [PubMed]

119. Levenson, V.V.; Melnikov, A.A. DNA Methylation as Clinically Useful Biomarkers-Light at the End of the Tunnel. Pharmaceuticals 2012, 5, 94-113. [CrossRef] [PubMed]

120. Reinius, L.E.; Acevedo, N.; Joerink, M.; Pershagen, G.; Dahlén, S.-E.; Greco, D.; Söderhäll, C.; Scheynius, A.; Kere, J. Differential DNA Methylation in Purified Human Blood Cells: Implications for Cell Lineage and Studies on Disease Susceptibility. PLoS ONE 2012, 7, e41361. [CrossRef] [PubMed]

121. Dahl, C.; Guldberg, P. DNA methylation analysis techniques. Biogerontology 2003, 4, 233-250. [CrossRef] [PubMed]

122. Brennecke, J.; Stark, A.; Russell, R.B.; Cohen, S.M. Principles of MicroRNA-Target Recognition. PLoS Biol. 2005, 3, e85. [CrossRef] [PubMed]

123. Lewis, B.P.; Burge, C.B.; Bartel, D.P. Conserved seed pairing, often flanked by adenosines, indicates that thousands of human genes are microRNA targets. Cell 2005, 120, 15-20. [CrossRef] [PubMed]

124. Peterson, S.M.; Thompson, J.A.; Ufkin, M.L.; Sathyanarayana, P.; Liaw, L.; Congdon, C.B. Common features of microRNA target prediction tools. Front. Genet. 2014, 5, 23. [CrossRef] [PubMed]

125. Lee, R.C.; Feinbaum, R.L.; Ambros, V. The C. elegans heterochronic gene lin-4 encodes small RNAs with antisense complementarity to lin-14. Cell 1993, 75, 843-854. [PubMed]

126. Hammond, S.M. An overview of microRNAs. Adv. Drug Deliv. Rev. 2015, 87, 3-14. [CrossRef] [PubMed]

127. Du, T. microPrimer: The biogenesis and function of microRNA. Development 2005, 132, 4645-4652. [CrossRef] [PubMed]

128. Sliwinska, A.; Kasinska, M.A.; Drzewoski, J. MicroRNAs and metabolic Disorders—Where are we heading? Arch. Med. Sci. 2017, 13, 885-896. [CrossRef] [PubMed]

129. Iacomino, G.; Siani, A. Role of microRNAs in obesity and obesity-related diseases. Genes Nutr. 2017. [CrossRef] [PubMed]

130. Papageorgiou, N.; Tousoulis, D.; Androulakis, E.; Siasos, G.; Briasoulis, A.; Vogiatzi, G.; Kampoli, A.-M.; Tsiamis, E.; Tentolouris, C.; Stefanadis, C. The role of microRNAs in cardiovascular disease. Curr. Med. Chem. 2012, 19, 2605-2610. [CrossRef] [PubMed]

131. He, Y.; Ding, Y.; Liang, B.; Lin, J.; Kim, T.-K.; Yu, H.; Hang, H.; Wang, K. A Systematic Study of Dysregulated MicroRNA in Type 2 Diabetes Mellitus. Int. J. Mol. Sci. 2017, 18, 456. [CrossRef] [PubMed]

132. Creemers, E.E.; Tijsen, A.J.; Pinto, Y.M. Circulating microRNAs: Novel biomarkers and extracellular communicators in cardiovascular disease? Circ. Res. 2012, 110, 483-495. [CrossRef] [PubMed]

133. Turchinovich, A.; Weiz, L.; Burwinkel, B. Extracellular miRNAs: The mystery of their origin and function. Trends Biochem. Sci. 2012, 37, 460-465. [CrossRef] [PubMed]

134. Chen, D.; Wang, W. Human Placental MicroRNAs and Preeclampsia. Boil. Reprod. 2013, 88, 130. [CrossRef] [PubMed]

135. Poirier, C.; Desgagné, V.; Guérin, R.; Bouchard, L. MicroRNAs in Pregnancy and Gestational Diabetes Mellitus: Emerging Role in Maternal Metabolic Regulation. Curr. Diabetes Rep. 2017, 17, 35. [CrossRef] [PubMed]

136. Zhao, C.; Dong, J.; Jiang, T.; Shi, Z.; Yu, B.; Zhu, Y.; Chen, D.; Xu, J.; Huo, R.; Dai, J.; et al. Early Second-Trimester Serum MiRNA Profiling Predicts Gestational Diabetes Mellitus. Zhang C, editor. PLoS ONE 2011, 6, e23925.

137. Tagoma, A.; Alnek, K.; Kirss, A.; Uibo, R.; Haller-Kikkatalo, K. MicroRNA profiling of second trimester maternal plasma shows upregulation of miR-195-5p in patients with gestational diabetes. Gene 2018, 672, 137-142. [CrossRef] [PubMed]

138. Wander, P.L.; Boyko, E.J.; Hevner, K.; Parikh, V.J.; Tadesse, M.G.; Sorensen, T.K.; Williams, M.A.; Enquobahrie, D.A. Circulating early- and mid-pregnancy microRNAs and risk of gestational diabetes. Diabetes Res. Clin. Prac. 2017, 132, 1-9. [CrossRef] [PubMed] 
139. Zhu, Y.; Tian, F.; Li, H.; Zhou, Y.; Lu, J.; Ge, Q. Profiling maternal plasma microRNA expression in early pregnancy to predict gestational diabetes mellitus. Int. J. Gynecol. Obstet. 2015, 130, 49-53. [CrossRef] [PubMed]

140. Cao, Y.-L.; Jia, Y.-J.; Xing, B.-H.; Shi, D.-D.; Dong, X.-J. Plasma microRNA-16-5p, -17-5p and -20a-5p: Novel diagnostic biomarkers for gestational diabetes mellitus. J. Obstet. Gynaecol. Res. 2017, 43, 974-981. [CrossRef] [PubMed]

141. Sebastiani, G.; Guarino, E.; Grieco, G.E.; Formichi, C.; Poggi, C.D.; Ceccarelli, E.; Dotta, F. Circulating microRNA (miRNA) expression profiling in plasma of patients with gestational diabetes mellitus reveals upregulation of miRNA miR-330-3p. Front. Endocrinol. 2017, 8, 345. [CrossRef] [PubMed]

142. Stirm, L.; Huypens, P.; Sass, S.; Batra, R.; Fritsche, L.; Brucker, S.; Abele, H.; Hennige, A.M.; Theis, F.; Beckers, J.; et al. Maternal whole blood cell miRNA-340 is elevated in gestational diabetes and inversely regulated by glucose and insulin. Sci. Rep. 2018, 8, 1366. [CrossRef] [PubMed]

143. He, Y.; Bai, J.; Liu, P.; Dong, J.; Tang, Y.; Zhou, J.; Han, P.; Xing, J.; Chen, Y.; Yu, X. miR-494 protects pancreatic B-cell function by targeting PTEN in gestational diabetes mellitus. EXCLI J. 2017, 16, 1297-1307. [PubMed]

144. Lamadrid-Romero, M.; Solís, K.H.; Cruz-Reséndiz, M.S.; Pérez, J.E.; Díaz, N.F.; Flores-Herrera, H.; Garcia-López, G.; Perichart, O.; Reyes-Muñoz, E.; Arenas-Huertero, F.; et al. Central nervous system development-related microRNAs levels increase in the serum of gestational diabetic women during the first trimester of pregnancy. Neurosci. Res. 2018, 130, 8-22. [CrossRef] [PubMed]

145. Wang, K.; Yuan, Y.; Cho, J.-H.; McClarty, S.; Baxter, D.; Galas, D.J. Comparing the MicroRNA Spectrum between Serum and Plasma. Ahuja SK, editor. PLoS ONE 2012, 7, e41561.

146. Dias, S.; Hemmings, S.; Muller, C.; Louw, J.; Pheiffer, C. MicroRNA Expression Varies according to Glucose Tolerance, Measurement Platform, and Biological Source. BioMed. Res. Int. 2017, 2017, e1080157. [CrossRef] [PubMed]

147. Schwarzenbach, H.; da Silva, A.M.; Calin, G.; Pantel, K. Which is the accurate data normalization strategy for microRNA quantification? Clin. Chem. 2015, 61, 1333-1342. [CrossRef] [PubMed]

148. Moen, G.-H.; Sommer, C.; Prasad, R.B.; Sletner, L.; Groop, L.; Qvigstad, E.; Birkeland, K.I. Mechanisms in endocrinology: Epigenetic modifications and gestational diabetes: A systematic review of published literature. Eur. J. Endocrinol. 2017, 176, R247-R267. [CrossRef] [PubMed]

149. Georgiou, H.M.; Lappas, M.; Georgiou, G.M.; Marita, A.; Bryant, V.J.; Hiscock, R.; Permezel, M.; Khalil, Z.; Rice, G.E. Screening for biomarkers predictive of gestational diabetes mellitus. Acta Diabetol. 2008, 45, 157-165. [CrossRef] [PubMed]

150. Shaat, N.; Groop, L. Genetics of gestational diabetes mellitus. Curr. Med. Chem. 2007, 14, 569-583. [CrossRef] [PubMed]

151. Krek, A.; Grün, D.; Poy, M.N.; Wolf, R.; Rosenberg, L.; Epstein, E.J.; MacMenamin, P.; da Piedade, I.; Gunsalus, K.C.; Stoffel, M.; et al. Combinatorial microRNA target predictions. Nat. Genet. 2005, 37, 495-500. [CrossRef] [PubMed]

(C) 2018 by the authors. Licensee MDPI, Basel, Switzerland. This article is an open access article distributed under the terms and conditions of the Creative Commons Attribution (CC BY) license (http:/ / creativecommons.org/licenses/by/4.0/). 